International Journal of Refrigeration

$$
\text { Elsevier Editorial System(tm) for }
$$

Manuscript Draft

Manuscript Number:

Title: A review on current status of capacity control techniques for twophase ejectors

Article Type: Review Paper

Keywords: Capacity control; Expansion work recovery; Multi-ejector; Needle ejector; Vapour-compression system; Vortex ejector

Corresponding Author: Dr. Paride Gullo, Ph.D.

Corresponding Author's Institution: Technical University of Denmark

First Author: Paride Gullo, Ph.D.

Order of Authors: Paride Gullo, Ph.D.; Martin Ryhl Kærn, Ph.D.; Michal Haida, Ph.D.; Jacek Smolka, Ph.D.; Stefan Elbel

Abstract: The adoption of highly efficient vapour-compression refrigeration, air conditioning and heat pump (RACHP) systems is compulsory to achieve a low-carbon society. Expansion work recovery using a two-phase ejector is widely recognized as one of the most promising measures to improve the energy efficiency of RACHP units. This holds true for all operation conditions provided that an effective capacity control technique is implemented. In this work a thorough critical review on the current status of the presently available capacity control techniques for two-phase ejectors was carried out. In addition, their pros and cons as well as the comparison of their performance were reported. It was concluded that two-phase ejectors can be properly capacity controlled in large- and medium-scale vapour-compression units. However, a suitable capacity control mechanism for small-scale vapour-compression solutions still requires a major breakthrough and is being intensively discussed among experts in the field.

Suggested Reviewers: Federico Mazzelli Ph.D. Prof., Department of Industrial Engineering, University of Florence federico.mazzelli@unifi.it

Well-known expert in two-phase ejectors

Nilesh Purohit Ph.D.

BITS Pilani

purohitnilesh89egmail.com

Well-known expert in two-phase ejectors

Neal Lawrence Ph.D.

RESEARCH ENGINEER, Creative Thermal Solutions

neal. lawrencelcreativethermalsolutions.com

Well-known expert in two-phase ejectors

Adriano Milazzo Ph.D.

Prof., Department of Industrial Engineering, University of Florence adriano.milazzo@unifi.it 
The accepted manuscript can be freely downloaded at: https://paridegullo.academia.edu/research

Well-known expert in two-phase ejectors

Yosr Allouche Ph.D.

Researcher, Department of Energy and Process Engineering, NTNU allouche.yosr@gmail.com

Well-known expert in two-phase ejectors 


\title{
A review on current status of capacity control techniques for two-phase ejectors
}

\author{
Paride Gullo $^{(a)}$,Martin Ryhl Karn ${ }^{(a)}$, Michal Haida ${ }^{(b)}$, Jacek Smolka ${ }^{(b)}$ and $^{2}$ \\ Stefan Elbel ${ }^{(c)}$ \\ ${ }^{(a)}$ Technical University of Denmark (DTU), Department of Mechanical Engineering, Nils Koppels \\ Allé, Building 403, 2800 Kgs. Lyngby (Denmark) \\ (b) Silesian University of Technology, Institute of Thermal Technology, Konarskiego 22, 44 - \\ 100 Gliwice (Poland) \\ ${ }^{(c)}$ University of Illinois at Urbana-Champaign, Department of Mechanical Science and \\ Engineering, 1206 West Green Street, 61801 Urbana, IL (USA)
}

\section{Corresponding author's details:}

- Paride Gullo

- Telephone number: +45 45254121

- Fax number: +4545251961

- Email addresses: parigul@mek.dtu.dk, paridegullo@gmail.com

\begin{abstract}
:
The adoption of highly efficient vapour-compression refrigeration, air conditioning and heat pump (RACHP) systems is compulsory to achieve a low-carbon society. Expansion work recovery using a two-phase ejector is widely recognized as one of the most promising measures to improve the energy efficiency of RACHP units. This holds true for all operation conditions provided that an effective capacity control technique is implemented. In this work a thorough critical review on the current status of the presently available capacity control techniques for two-phase ejectors was carried out. In addition, their pros and cons as well as the comparison of their performance were reported. It was concluded that two-phase ejectors can be properly capacity controlled in large- and medium-scale vapour-compression units. However, a suitable capacity control mechanism for small-scale vapour-compression solutions still requires a major breakthrough and is being intensively discussed among experts in the field.
\end{abstract}

\section{Keywords:}

Capacity control; Expansion work recovery; Multi-ejector; Needle ejector; Vapour-compression system; Vortex ejector 


\section{Highlights}

- Two-phase ejectors are expected to lead to a significantly more sustainable future

- Benefits from two-phase ejectors strongly depend on their capacity control strategy

- Capacity control mechanisms for two-phase ejector are comprehensively reviewed

- Two-phase ejectors can be capacity controlled in large- and medium-scale units

- Capacity control method for small-scale units still requires a major breakthrough 


\section{Introduction}

Vapour-compression refrigeration, air conditioning and heat pump (RACHP) systems play a key role in modern life, being extensively employed for satisfying many fundamental human needs, such as food preservation, medicine storage, water heating and cooling/heating of living spaces. However, their massive use leads the RACHP sector to be dramatically energy intensive, contributing to global warming significantly. Refrigeration and air conditioning alone are accountable for about $20 \%$ of the worldwide electricity consumption (IIR, 2019). Peters (2018) claims that the cooling sector is bound to increment its global energy consumption by more than $90 \%$ by 2050 in comparison with levels defined in 2018, if the cooling sector is not improved. This growing thermal need is a driving force for greenhouse gas (GHG) emissions worldwide. According to Isaac and van Vuuren (2009), GHG releases related to cooling applications could double by 2030, if no appropriate actions are adopted. Therefore, climate change mitigation by enhancing energy efficiency of RACHP units becomes increasingly important. In this regard, the European Union committed to cut GHG emissions by at least $40 \%$ below 1990 levels by 2030 and, simultaneously, to enhance the energy efficiency by at least $32.5 \%$ by 2030 (European Commission, 2019).

A two-phase ejector used for expansion work recovery is well-recognized as a promising solution allowing for highly efficient vapour-compression RACHP systems (Elbel, 2011; Sarkar, 2012; Sumeru et al., 2012). The adoption of a suitable capacity control strategy is crucial to two-phase ejectors in order to maximize the coefficients of performance (COPs) of vapour-compression RACHP systems over all the operation conditions (Sumeru et al., 2012). This is due to the fact that the performance of two-phase ejectors is significantly governed by their four characteristic dimensions (i.e. suction nozzle, motive nozzle, mixing chamber and diffuser), which need to be permanently suited to the operating conditions so as to implement an appropriate capacity control along with an effective expansion work recovery (Liu et al., 2012c). According to Elbel and Lawrence (2016), the adoption of a two-phase ejector leads to COP enhancements between $10 \%$ and $30 \%$ for R744 vapourcompression units at the design conditions. However, the authors also highlighted the crucial importance of controlling the ejector, since its performance at various outdoor temperatures and cooling capacities (i.e. off-design operations) is dramatically penalized. Lucas and Koehler (2012) showed experimentally that an R744 two-phase ejector with fixed-type geometry (i.e. passive ejector, meaning no active control implemented) results in reductions in COP up to 17\%, as the gas cooler pressure was $0.5 \mathrm{MPa}$ above the optimal operation condition. The experimental results by Poolman et al. (2018) highlighted that the use of a passive ejector causes an increase in annualized energy consumption by $6 \%$ compared with the same solution without ejector in container refrigeration units. $\mathrm{Hu}$ et al. (2014) experimentally proved that, for a given operating condition, different nozzle diameters can entail differences in energy efficiency ratio (EER) by more than $40 \%$. Slightly different geometries could lead to considerably different COPs at the same boundary conditions (Hu et al., 2014; Zhu and Elbel, 2016a, 2016b). It is worth remarking that most of the RACHPs, regardless of their scale and purpose, operates most of the time at off-design operation. The need for a novel capacity control technique for two-phase ejector is explained by Zhu and Elbel (2016a, 2016b) as follows: "A variable geometry ejector with adjustable needle in the motive nozzle can optimize ejector cycle performance under different conditions, but this design is complicated and costly, and more frictional losses are incurred because of the additional surface area introduced which results in lower nozzle and ejector efficiencies. This provides motivation to develop a new technology to control the motive nozzle restrictiveness".

Despite the wide number of review works on two-phase ejectors (Elbel, 2011; Sarkar, 2012; Sumeru et al., 2012; Chen et al., 2013; Besagni et al., 2016; Elbel and Lawrence, 2016; Tashtoush et al., 2019; Besagni, 2019; Aidoun et al., 2019; Ringstad et al., 2019), their crucial role in steering society towards sustainability (Elbel, 2011; Sarkar, 2012; Sumeru et al., 2012) and the key importance of their capacity control mechanism to achieve this target (Sumeru et al., 2012), no review work is currently available targeting the capacity control mechanism of these devices, to the best of the authors' 
knowledge. Therefore, the goal of the present investigation is to fill this knowledge gap by thoroughly reviewing the current status on capacity control mechanisms for two-phase ejectors. The work is organized as follows: the current status on today's most employed capacity control techniques are described and commented in Section 2, while their pros and cons as well as their performances are compared in Section 3. Finally, the conclusions and future developments are summarized in Section 4.

\section{Capacity control techniques for two-phase ejectors}

The diameter of the throat of the ejector motive nozzle plays a crucial role in the capacity control of two-phase ejectors and thus in the achievement of high COPs (Sarkar, 2012; Hu et al., 2014). This geometric characteristic can be varied with the aid of a needle, as suggested by Elbel and Hrnjak (2008) and Liu and Groll (2008) (Figure 1a). In addition, to the best of the authors' knowledge, two capacity control methods requiring no geometry change are also currently under investigation:

i. the multi-ejector concept (Figure 1b) (Hafner et al., 2012, 2014a), which has been developed uniquely for medium- and large-scale transcritical R744 applications (mainly supermarkets);

ii. the adjustable vortex-based capacity control strategy (Figure 2) (Zhu and Elbel, 2016a, 2016b). The capacity control mechanism relying on the use of an expansion valve installed either upstream or in parallel of the ejector (Figure 1c) is mainly adopted as a baseline for the aforementioned capacity control techniques (Lawrence and Elbel, 2019; Zhu and Elbel, 2020).

\subsection{Adjustable needle-based capacity control technique}

The adjustable needle-based ejector (Figure 1a) features a conical needle type control aimed at modifying the mass flow rate through the motive nozzle by varying the needle location in the convergent part of the motive nozzle with respect to the operation conditions. The first experimental results related to this solution were presented by Elbel and Hrnjak (2008) and Liu and Groll (2008) for a transcritical R744 vapour-compression system.

\subsubsection{Air conditioning and refrigeration applications: effect of ejector geometries and operating conditions}

Zhu and Elbel (2016a, 2016b) claimed that the adoption of the needle increases the frictional losses due to the larger surface area, leading to poor nozzle and ejector efficiencies. This result was experimentally verified by Elbel and Hrnjak (2008) and Lawrence and Elbel (2016d). However, the authors also found that the high-side pressure control can counterbalance the penalizations in nozzle and ejector efficiencies.

The experimental work by Liu et al. (2012a) regarding a transcritical R744 air conditioner using a two-phase ejector revealed that the COP enhancement was greater as the outdoor air temperature increased as well as the motive nozzle throat diameter and the compressor frequency decreased. In regards to the motive nozzle throat diameter, its variation led to COP and cooling capacity improvements by up to $60 \%$ and $46 \%$, respectively. In comparison with the basic system running at a constant compressor speed of $50 \mathrm{~Hz}, \mathrm{COP}$ and cooling capacity can be improved by changing the compressor speed by up to $147 \%$ and $25 \%$, respectively. In addition, the authors observed that the influence of the ejector geometries on the suction mass flow rate was not noteworthy. Finally, it was found that the best COP value is attained as the distance between the motive nozzle exit and the mixing section entrance is three times the mixing section diameter. Liu and Groll (2008) and Liu et al. (2012b) observed that, for two-phase ejectors installed in transcritical R744 refrigeration units, the motive nozzle efficiency goes down as the ejector throat area is reduced. In addition, it was found that the suction nozzle efficiency depends on the outdoor temperature as well as on the ejector throat area. Lastly, the results obtained also demonstrated that the distance from the motive nozzle outlet to 
the mixing section constant area inlet influences both the suction nozzle efficiency and the mixing section efficiency.

The isentropic efficiencies of the ejector components were determined with the aid of a simulation model combined with measured data by Liu and Groll (2013). Taking into account a transcritical R744 air conditioner operating at outdoor air temperatures of $27.8{ }^{\circ} \mathrm{C}, 35{ }^{\circ} \mathrm{C}$ and $37.8{ }^{\circ} \mathrm{C}$, it was observed that:

- the suction nozzle efficiency ranged between 0.37 and 0.90 and is influenced by the motive nozzle throat diameter, motive nozzle outlet position and outdoor air temperature;

- the efficiency of the mixing section ranged between 0.50 and 1.00 and depends on the motive nozzle outlet position and outdoor air temperature. Furthermore, a small motive nozzle throat diameter implies a low motive nozzle efficiency and a high suction nozzle efficiency;

- the motive nozzle efficiency ranged between 0.50 and 0.93 and is strongly related to the ejector throat diameter.

Zheng and Deng (2017) evaluated the efficiencies of an ejector operating in a transcritical R744 vapour-compression unit by combining the results of the experimental data and a theoretical model. The results obtained were in the range of $0.74 \div 0.89,0.86 \div 0.96,0.73 \div 0.9$ and $0.75 \div 0.95$ for the motive nozzle, suction nozzle, mixing section and diffuser, respectively.

A simulation model of an ejector-equipped transcritical R744 (air-to-air) air conditioner was developed and validated by Liu et al. (2012c). The results obtained revealed that a maximum value of cooling capacity and COP can be attained as the motive nozzle throat diameter is $2.8 \mathrm{~mm}$ and the mixing section constant-area diameter is between $4.1 \mathrm{~mm}$ and $4.2 \mathrm{~mm}$. The performance of the investigated solution improved as the ejector motive nozzle throat diameter decreases.

The experimental investigation by Jeon et al. (2017a) aimed at evaluating the influence of the ejector geometries on the performance of an R410A air conditioner using a two-phase ejector. The authors concluded that the optimal mixing section diameter was found to enlarge, as the annual average outdoor temperature increases.

The study by Zheng et al. (2015) revealed that the regulation of the throat area of the ejector motive nozzle influenced the system performance considerably more than that of the chilled water volume flow rate of the second evaporator.

Hou et al. (2017) investigated the influence of the key ejector geometric parameters (i.e. primary nozzle diameter, area ratio, mixing chamber length) on the performance of a parallel hybrid R134a refrigerator-freezer cooling unit. The results obtained showed that the entrainment ratio barely varied as the needle throat area was reduced from $0 \%$ to $20 \%$, whereas it changed substantially between $20 \%$ and $40 \%$. In addition, the entrainment ratio was relatively high (above 1) as the needle blocking percentage is below $30 \%$.

Lin et al. (2012) developed a computational fluid dynamics (CFD) model (validated and adjusted against experimental data) of an R134a two-phase ejector installed in a multi-evaporator refrigeration system. The results indicated that low air conditioning (AC) loads can lead to poor pressure recovery ratios (PRRs), revealing the need for capacity control in order to keep the PRR at acceptable values over the whole range of AC demand. Considering the potential system instability due to the primary and secondary flow rates being different from the designed conditions, the authors highlighted to pay close attention to the problems deriving from a complicated and difficult system control by employing the adjustable needle and the compressor. At a later time, Lin et al. (2013a) proved experimentally that the PRR could reach as much as $20 \%$ at the design conditions. Furthermore, it was found that the PRR decreases as the primary cooling load decreases. The same authors (Lin et al., 2013b) found that that the PRR is strongly related to the length of the constant-pressure mixing section as well as to the nozzle diverging angle.

The study by He et al. (2019) showed that the highest exergy destruction in a needle-based ejector of a transcritical R744 unit presenting two-stage evaporation takes place in the suction chamber. This was caused by the flow separation along the needle and higher viscous dissipation of the oblique shock wave. Therefore, the authors calculated a $5 \% \div 11 \%$ lower entrainment ratio than for a passive 
ejector. On the other hand, the exergy efficiency of the passive ejector was found to be only $0.5 \%$ higher than that of the needle-based ejector owing to the higher speed in the former, causing higher flow separation in the diffuser and higher wall friction.

Jeon et al. (2017b) experimentally studied nozzle position and mixing section diameter of a needlebased ejector installed in an R600a domestic refrigerator-freezer relying on a condenser outlet split. The best PRR was evaluated at the nozzle position of $0 \mathrm{~mm}$ and $3 \mathrm{~mm}$ for low and high entrainment ratios, respectively. At low entrainment ratio and compressor speed, an optimal mixing section diameter of $2.5 \mathrm{~mm}$ was found to maximize COP, whereas at high entrainment ratio and compressor speed an optimal mixing section diameter of $3.5 \mathrm{~mm}$ was computed. At a later time, Jeon et al. (2018) experimentally revealed that the proposed solution features a similar temperature profile in the freezer compartment to that showed by a basic domestic refrigerator-freezer unit at the compressor speed of $1450 \mathrm{rpm}$.

\subsubsection{Air conditioning and refrigeration applications: performance and cooling capacity enhancement}

The outcomes obtained by Elbel and Hrnjak (2008) suggested that the COP and cooling capacity can be concurrently enhanced by up to $7 \%$ and $8 \%$ over the investigated operating conditions. The most favourable value of pressure recovery was observed for a diffuser angle of $5^{\circ}$, while ejector efficiencies up to 0.145 were obtained. In addition, it was extrapolated that the COP could have achieved enhancements by up to $18 \%$ for matched cooling capacities.

Liu et al. (2012c) estimated that, at the outdoor air temperature of $37.8^{\circ} \mathrm{C}$, COP and cooling capacity can be enhanced by about $30.7 \%$ and $32.1 \%$, respectively, over a conventional R744 system.

Hu et al. (2014) suggested the adoption of an R410A vapour-compression system using an adjustable needle for AC purposes. However, the authors experimentally found that, in comparison with the system relying on an electronic expansion valve, the increase in EER was limited. In addition, the results obtained revealed that in one of the investigated operating conditions the aforementioned baseline could outperform the system employing the ejector. The authors argued that the significant loss of kinetic energy caused by the inappropriate roughness of the internal surface as well as the use of non-optimized mixing section length and diffuser angle could explain this result.

Lawrence and Elbel (2016a, 2016c, 2019) showed experimentally that the needle-based ejector leads to an increase in COP between $2 \%$ and $4 \%$ compared to the passive ejector. The study was based on the operation conditions of AC applications $\left(\mathrm{T}_{\text {air,evap_inlet }}=27^{\circ} \mathrm{C}, \mathrm{T}_{\text {air,gc_inlet }}=30 \div 40^{\circ} \mathrm{C}\right)$. Furthermore, the results revealed that the ejector performance penalization due to the use of the needle-based ejector (lowest ejector efficiency $=0.213$ ) is substantially higher than those caused by off-design operations (lowest ejector efficiency $=0.164$ ). At a later time, the same authors (Lawrence and Elbel, 2016b) found that the needle-based strategy can be successfully extended to subcritical operation conditions, leading to increases in COP by up to $3 \%$ when compared to the passive ejector $\left(\mathrm{T}_{\text {air,evap_inlet }}\right.$ $=20^{\circ} \mathrm{C}, \mathrm{T}_{\text {ambient }}=20^{\circ} \mathrm{C}$ ).

Kim et al. (2018) experimentally evaluated the performance of an R410A air conditioning unit, relying on a needle-based ejector and a dual evaporator. The results obtained showed that, in comparison with the conventional ejector-based solution, an improvement in cooling seasonal performance factor (CSPF) by $6.3 \%$ can be achieved at an entrainment ratio of 0.1 .

Recently, Poolman et al. (2018) evaluated the benefits from adopting an adjustable two-phase ejector in a transcritical R744 vapour-compression system employing two-stage compressor with intercooler in container refrigeration applications. The test outcomes showed that the use of the aforementioned device allows for $1.3 \%$ annualized energy consumption reduction.

Zheng et al. (2016) implemented a dynamic model of a transcritical R744 system equipped with a two-phase ejector with and without two-stage evaporation and validated the model against experimental data. At the investigated operation conditions, the COP was found to range between 2.40 and 3.58 for the advanced solution, whereas a conventional R744 system equipped with a twophase ejector could obtain COP values from 2.10 and 2.50 . 
Ferrarese et al. (2018) predicted that the use of a needle-based ejector in a transcritical R744 supermarket refrigeration system would lead to an annual energy saving between $6 \%$ and $9 \%$ when compared to a conventional booster unit in warm locations. The authors also predicted that the further optimization of the ejector activation along with an increase in the evaporating temperature would permit yearly energy savings between $10 \%$ and $14 \%$.

The study by Jeon et al. (2017a) revealed that, as the optimal mixing section diameter is considered, the CSPF enhances from $16.0 \%$ (in Seattle, USA, annual average outdoor temperature of $11.5^{\circ} \mathrm{C}$ ) to $20.3 \%$ (in Hong Kong, China, annual average outdoor temperature of $29.1^{\circ} \mathrm{C}$ ) in comparison with a conventional vapour-compression unit, depending on the selected location. In addition, a maximum enhancement in COP by $7.5 \%$ compared to a conventional vapour-compression unit was assessed at the medium-capacity mode (i.e. compressor speed of $2340 \mathrm{rpm}$, condensing pressure of $2763 \mathrm{kPa}$, evaporating pressure of $1184 \mathrm{kPa}$ ).

Jeon et al. (2017b) observed that at the compressor speed of $45 \mathrm{~Hz}$ and entrainment ratio of 0.3 , the maximum COP improvement relying on the optimal mixing section diameter was $6.8 \%$ compared to a conventional vapour-compression unit. In a following study, the authors experienced that the investigated system offers energy savings of $10.9 \%$ compared to the same baseline at a similar cooling duty and compressor speed of $1450 \mathrm{rpm}$ (Jeon et al., 2018).

\subsubsection{Heat pump applications}

$\mathrm{Xu}$ et al. (2012) experimentally studied the performance of a transcritical R744 heat pump unit relying on a two-phase ejector at different cooling water flow rate. The results obtained revealed that as the gas cooler pressure increases, the maximum values of $\mathrm{COP}_{\text {heating }}$ and heating capacity can be attained by inserting the needle into the motive nozzle throat. Furthermore, the ejector efficiencies were found to range mainly between 0.2 and 0.3 and to decrease as the gas cooler pressure increases. However, the negative effect on the ejector efficiency related to the increase in the gas cooler pressure was compensated by the benefits gained in terms of $\mathrm{COP}_{\text {heating. }}$.

An experimental evaluation of the performance of a transcritical R744 unit simultaneously performing cooling and heating was implemented by Liu et al. (2016). At the investigated operation conditions, the COP could be enhanced by up to $71.4 \%$, whereas the system capacity decreased as much as $21.3 \%$.

\subsubsection{Proposed measures for adjustable needle-based capacity control technique enhancement}

To the best of the authors' knowledge, three measures were recently suggested to further improve the adjustable needle-based capacity control technique.

Ren et al. (2014) proposed the adoption of a needle-based two-throat nozzle ejector (Figure 3). In a conventional two-phase ejector, significant differences in velocity between the vapour and the liquid components of the refrigerant mixture at the outlet of the motive nozzle occur due to large droplet diameters of the liquid component. As a consequence, the entrainment ratio is penalized. In the solution proposed by Ren et al. (2014), the vapour-liquid refrigerant mixture exiting the first nozzle enters the second nozzle where the liquid refrigerant droplets are broken up, reducing their size. It was experimentally found that the two-throat nozzle ejector presented higher COPs (maximum increment of $12 \%$ ) and entrainment ratios (maximum increment of $18 \%$ ) compared with the conventional two-phase ejector (called de Laval nozzle in Figure 4) at the condensing temperature of $45^{\circ} \mathrm{C}$ and evaporating temperature of $1{ }^{\circ} \mathrm{C}$.

He et al. (2017a, 2017b) implemented an optimum multivariable controller for a transcritical R744 refrigeration system using a needle-based ejector to enhance its performance by adjusting the compressor speed and the throat area. It was experimentally found that this solution is capable of gradually approaching the maximum $\mathrm{COP}_{\text {cooling }}$ in about $700 \mathrm{~s}$ over the investigated operation conditions. 
Chen et al. (2019) suggested a subcooling control method to modulate a needle-based ejector in a direct expansion solar refrigeration unit by adopting proportion integration differentiation (PID) algorithm. The experimental outcomes revealed that the equipment mentioned above can keep a subcooling degree of $4 \div 7{ }^{\circ} \mathrm{C}$, decrease the power input by between $6.24 \%$ and $6.99 \%$ and enhance the average heating capacity by between $5.41 \%$ and $7.20 \%$. The authors also found that the benefits are mainly ascribable to the upgrading in entrainment ratio.

\subsubsection{Summary of the current status on the adjustable needle-based capacity control technique}

The main findings associated with the adjustable needle-based capacity control mechanism are summed up in Table 1. In accordance with them, it is possible to claim that such a technique:

- needs to be properly designed, since the ejector geometries significantly affect its performance;

- can lead transcritical R744 units to achieve great energy savings compared to conventional transcritical R744 systems, whereas the benefits seem to be limited compared to R744 solutions using a passive ejector working largely in off-design conditions;

- there is a dramatic lack of comparative studies between transcritical R744 units using needle-based ejectors and the corresponding hydrofluorocarbon (HFC)-based competitors;

- has to be precisely operated due to the significant performance drop near critical closing nozzle position (Smolka et al., 2016);

- appears to be less advantageous for HFC-based air conditioners, whereas it was found to be promising for domestic refrigerator-freezers.

\subsection{Multi-ejector based capacity control technique}

The multi-ejector concept was formulated by Hafner et al. (2012, 2014a) for medium- and largecapacity applications (e.g. supermarkets, reversible heat pumping equipment) relying on R744. The multi-ejector arrangement is characterized by the presence of $4 \div 6$ vapour ejectors with fixed geometry and different size. The combination of vapour ejectors in use determinates the capacity provided by the system. As shown in Figure 1b, a solenoid valve is installed upstream of each cartridge to individually activate each of the available ejectors. An expansion valve is installed in parallel to the multi-ejector block to guarantee that the required capacity can be achieved at any operation condition as fixed size ejectors can only provide incremental capacity steps. Therefore, the fine control through the parallel valve occurs at the expense of some of the available expansion work recovery.

\subsubsection{Large-scale applications}

Two different investigations demonstrated with the aid of field measurements the need for at least 3 ejectors to properly modulate the capacity (Schönenberger et al., 2014; Hafner et al., 2014b).

The extensive experimental campaign carried out by Banasiak et al. (2015) proved that the multiejector block has a similar error profile of gas cooler pressure caused by a fast variation in both capacity and external ambient temperature to that of a conventional electronic expansion valve. Furthermore, the maximum increase in COP was observed to be equal to $9.8 \%$. The COP and exergy efficiency of a transcritical R744 unit equipped with parallel compression can be enhanced by up to $7 \%$ and $13.7 \%$, respectively, with the aid of the multi-ejector concept (Haida et al., 2016). The vapour ejector efficiencies were found to be above 0.25 as taken from the field (Fredslund et al., 2016) and above 0.3 as taken in the laboratory.

The numerical study by Bodys et al. (2016) revealed that use of a swirl generator upstream of the motive nozzle of R744 ejectors with different size and belonging to a multi-ejector block can increase the mass entrainment ratio by up to $3 \%$. 
Multi-ejector R744 booster refrigerating systems integrated with the AC equipment were found to reduce the annual energy consumption by at least $15.6 \%$ compared to separated HFC-based units in warm locations (Gullo et al., 2017). The theoretical study by Gullo et al. (2018a, 2018b) brought to light that the multi-ejector concept is hypothetically capable of moving the so-called " $\mathrm{CO}_{2}$ equator" (Matthiesen et al., 2010) below the North of Africa. Gullo (2019) theoretically investigated the energy and environmental performance of R744 multi-ejector enhanced parallel compression systems implementing direct space heating and cooling in high ambient temperature cities. The results obtained revealed that these solutions feature yearly energy savings and environmental impact decreases respectively by up to $33.3 \%$ and $89.5 \%$ over HFC-based units. The adoption of the multiejector concept was also recently justified with the aid of exergy analysis (Gullo et al., 2019).

The field measurements collected by various researchers revealed that energy savings between $10 \%$ and $14 \%$ can be obtained compared to the solution relying on parallel compression in cold climates (Schönenberger et al., 2014; Hafner et al., 2014b). At outdoor temperatures from $22{ }^{\circ} \mathrm{C}$ to $35{ }^{\circ} \mathrm{C}$, energy consumption reductions between $15 \%$ and $30 \%$ (depending on the AC duty and external ambient temperature) were observed when compared to a parallel compression-based system (Hafner et al., 2016).

\subsubsection{Medium-scale applications}

Boccardi et al. $(2016,2017)$ experimentally investigated the performance of an air-to-water reversible R744 heat pump unit relying on the multi-ejector concept. At the nominal operating conditions (i.e. heating capacity of about $30 \mathrm{~kW}$, water inlet temperature of $40^{\circ} \mathrm{C}$, water outlet temperature of $60^{\circ} \mathrm{C}$, air temperature of 7 or $12^{\circ} \mathrm{C}$ ), the authors found that the performance can be maximized by shifting from an ejector configuration to another as the ambient temperature varies.

\subsubsection{Summary of the current status on the multi-ejector based capacity control technique}

The main findings associated with the multi-ejector concept are presented in Table 2. As showed by Gullo et al. (2018c), the diffusion of transcritical R744 supermarket refrigerating plants worldwide is mainly due to the multi-ejector concept. The promising results obtained in developed countries have drawn the interest of developing countries (i.e. hot climate locations) for both large- (Blust et al., 2018; Singh et al., 2018a) and medium-scale (Singh et al., 2018b) applications. However, as concluded by Boccardi et al. $(2016,2017)$, since two-phase ejectors are expected to lead to great results, more investigations on heat pump units relying on ejectors specifically tailored for these purposes are necessary.

Finally, it is of great importance to highlight that, in regards to small-capacity applications, this capacity-control mechanism also features some drawbacks, such as significant complexity (Elbel and Lawrence, 2016), considerable cost (Madsen and Kriezi, 2018; Zhu and Elbel, 2020) and limits in terms of manufacturing sizes.

\subsection{Adjustable vortex-based capacity control technique}

An innovative capacity control mechanism was recently proposed by Zhu and Elbel (2016b). The researchers designed and manufactured a nozzle in which an adjustable vortex at its inlet is generated to control the nozzle restrictiveness (and thus the ejector capacity) without varying the nozzle geometry dimensions. The authors defined the ejector and adjustable nozzle relying on this control technique as the vortex ejector and vortex nozzle, respectively. Figure 2 highlights that the cycle of a vortex ejector system differs from that of a conventional ejector unit uniquely because the refrigerant mass flow rate coming out of the condenser (or of the gas cooler in case of R744) is divided into two parts. One stream goes into the vortex ejector through the motive flow tangential inlet, whereas the other through the motive flow axial inlet. This leads to the generation of a vortex at the 
ejector motive inlet. A valve installed at the motive flow tangential inlet allows regulating the ratio of the two aforementioned streams and thus varying the vortex strength (vortex strength $=$ $\left.\dot{\mathrm{m}}_{\text {tangential }} / \dot{\mathrm{m}}_{\text {total }}\right)$.

According to the authors, the pressure drop across the control valve is generally negligible. The effect of the vortex strength on the overall R134a mass flow rate going into the motive nozzle is presented in Figure 5 at constant inlet conditions. The stronger the inlet vortex, the lower mass flow can be driven through the nozzle (i.e. the larger the nozzle restrictiveness is). The results obtained highlighted that the mass flow rate can be decreased by $36 \%$ with the proposed control technique at the same inlet and outlet conditions.

Zhu and Elbel (2018d) extended the previously mentioned work by including six other nozzle geometries relying on R134a. A maximum vortex control range of $42 \%$ was assessed.

The subcooled flashing vortex flow of the convergent nozzle belonging to the vortex ejector was modelled by Zhu and Elbel (2016c) at steady state by implementing two different approaches. The first approach considered that the bubble nucleation during the depressurization within the nozzle completely took place at the nozzle wall. The second one was based on the presence of an evaporation wave at the nozzle throat and the refrigerant in the upstream of the evaporation wave is evaluated as a single-phase incompressible liquid. The latter revealed lower discrepancies as compared to experimental results for choked flow.

At a later time, Zhu and Elbel $(2017,2018 \mathrm{~d})$ experimentally studied the influence of nozzle divergent part length and nozzle throat diameter on the vortex control of initially subcooled flashing R134a. The results obtained showed that the control range decreases as a result of a decrease on the nozzle throat diameter. In addition, it was found that in case of zero divergent part length of the motive nozzle, the inlet vortex strength does not influence the total mass flow rate. If the same convergent part, throat diameter and divergent angle were adopted, the results revealed that the longer the divergent part of the nozzle is, the larger the vortex control range is. This means that the divergent part of the nozzle plays a crucial role for choking and vortex control of an initially subcooled flashing flow.

The experimental work by Zhu and Elbel aimed at evaluating the applicability of vortex control to mobile air conditioning (MAC) equipment (Zhu and Elbel, 2018a) and AC (Zhu and Elbel, 2018b, $2018 \mathrm{c}$ ) units relying on a transcritical R744 vapour-compression system. The authors showed that, under common boundary conditions, the motive inlet pressure can be ranged between 86.09 bar and 96.37 bar for constant total motive mass flow rate and motive inlet temperature. Moreover, it was found that the vortex ejector efficiency reduces by about $47 \%$ from 0.187 to 0.099 with rise in vortex strength, as presented in Figure 6. It should be noted, however, that these results were obtained with vortex nozzle geometries, which can have not been fully optimized.

The experimental evaluations performed by Zhu and Elbel (2018e, 2018f) demonstrated that, at the same inlet and outlet operation conditions, the implemented vortex leads to the generation of more vapour in the divergent part of the motive nozzle. This allows the outgoing flow to approach the thermodynamic equilibrium. Furthermore, the authors evaluated enhancement in nozzle isentropic efficiency from 29\% to 55\% (Zhu and Elbel, 2018e) and from 22.4\% to 41.3\% (Zhu and Elbel, 2018f). Zhu and Elbel (2018g) carried out a CFD analysis of initially subcooled vortex flashing flows in convergent-divergent nozzles. The outcomes obtained revealed that, in agreement with the collected experimental data, the nozzle restrictiveness increases after applying the inlet vortex. Moreover, it was found that owing to the more available liquid sensible heat, as a consequence of the introduction of inlet vortex, the vapour generated in the nozzle divergent part intensifies and the flow control can be implemented. Very recently, the same authors (Zhu and Elbel, 2019) extended the previous work and discovered that the use of the vortex increases the nozzle outflow axial velocity by $30.1 \%$ as the vortex strength increases from 0 to $1\left(\mathrm{P}_{\text {inlet }}=925 \mathrm{kPa}, \mathrm{T}_{\text {inlet }}=36.0^{\circ} \mathrm{C}, \mathrm{P}_{\text {outlet }}=615 \mathrm{kPa}\right)$, although the mass flow rate decreases from $16.0 \mathrm{~g} \cdot \mathrm{s}^{-1}$ to $12.6 \mathrm{~g} \cdot \mathrm{s}^{-1}$. In addition, it was found that the isentropic efficiency of the nozzle enhances from $37.7 \%$ to $63.8 \%$. 
Zhu and Elbel (2020) experimentally proved that the aforementioned capacity control can increase the R744 system capacity and COP by $11 \%$ and $8.1 \%$ under off-design operation conditions,

\subsubsection{Summary of the current status on the adjustable vortex-based capacity control technique}

The main findings related to the vortex-based capacity control strategy are summarized in Table 3 . In accordance with them, it could be claimed that the nozzle restrictiveness can be suitably varied with the aid of the nozzle inlet vortex as well as that the capacity modulation is potentially wide enough to be considered for real applications (Zhu and Elbel, 2018d). In addition, according to the studies implemented by the authors of this concept, vortex ejectors are potentially suitable for smallcapacity applications, such as MAC units and air conditioners. This could promote a much wider use of R744 as the sole working fluid in small-scale RACHP sector too. However, to the best of the authors' knowledge, this technique is still under investigation on a laboratory scale, being currently in its infancy.

\section{Comparison}

The pros and cons as well as the performance of the various available capacity control techniques for two-phase ejectors are summarized in Table 4 and Table 5, respectively.

\subsection{Multi-ejector control vs. needle-based capacity control}

Smolka et al. (2016) compared the performance of four fixed-geometry ejectors installed into a multiejector block with that of needle-based ejectors presenting convergent and convergent-divergent nozzles in an R744 refrigerating plant. It was found that, for the convergent-divergent nozzle and at low restrictiveness of the throat area of the motive nozzle, similar efficiencies to those of fixedgeometry ejectors can be measured. In addition, the efficiency was in most cases $25 \%$ higher than for the latter as the motive nozzle throat was decreased by about 35\%, after which the efficiency progressively went down. On the other hand, the needle position was challenging to be unambiguously evaluated at all the assessed operation conditions. Lawrence and Elbel (2019) highlighted the need for further investigations aimed at revealing whether an adjustable needle ejector or a multi-ejector block present better efficiency.

Zhu et al. (2018a, 2018b, 2018c) experimentally proved that in an ejector-equipped transcritical R744 unit, as the motive nozzle needle gets close to the nozzle throat, the evaporator oil circulation rate as well as the flow rate at the compressor discharge decrease substantially. The multi-ejector based solution was found to face similar severity in terms of oil circulation rate in the evaporator with those tackled by a conventional ejector cycle (Zhu et al., 2018c).

\subsection{Vortex-based capacity control vs. needle-based capacity control}

The innovative capacity control strategy proposed by Zhu and Elbel (2016a, 2016b) features more simplicity, (potentially) lower cost, lower vulnerability to clogging (no need to change the flow area) as well as lower frictional losses compared to the needle-based method. On the one hand, the experimental work carried out by Zhu and Elbel (2020) brought to light that, at the same boundary conditions, the needle-based capacity control offers the best performance with respect to optimum capacity and COP compared with the vortex-based capacity control. On the other hand, the readers should be reminded that the vortex ejector design is still in its early stages of development and not as mature as its needle-controlled counterpart. 


\subsection{Needle-based capacity control vs. expansion valve-based capacity control}

Referring to Figure 7, as the gas cooler pressure increase (by up to 8 bar), the series expansion valve control presents up to $1.5 \%$ lower COP than the adjustable needle ejector control (Lawrence and Elbel, 2019). However, the maximum COP offered by these two methods is very similar. In addition, Lawrence and Elbel (2019) found that the work recovery efficiency of the series expansion valve control is up to $2.3 \%$ lower than that of the adjustable ejector as the high pressure increases by up to 8 bar. Therefore, the authors concluded that the former represents a cheaper and simpler solution offering similar performance in comparison with the needle-based ejector control.

\subsection{Vortex-based capacity control vs. expansion valve-based capacity control}

Zhu and Elbel (2020) experimentally compared the performance of four ejectors with different geometry relying on the vortex control technique with that of four ejectors based on the series expansion valve control mechanism. The results obtained revealed that compared with the series expansion valve control:

- at the operating condition No. $1\left(\mathrm{~T}_{\mathrm{HP}, \mathrm{IHX} \_ \text {outlet }}=31.9^{\circ} \mathrm{C}, \mathrm{P}_{\mathrm{sn} \_ \text {inlet }}=38.02 \mathrm{bar}, \mathrm{T}_{\mathrm{sn} \_ \text {inlet }}=7.4{ }^{\circ} \mathrm{C}, \dot{\mathrm{m}}_{\mathrm{mn}}\right.$ $\left.=43.1 \mathrm{~g} \cdot \mathrm{s}^{-1}, \dot{\mathrm{m}}_{\mathrm{sn}}=22.8 \mathrm{~g} \cdot \mathrm{s}^{-1}\right)$, the vortex control features slightly lower values of both pressure and work recovery efficiency;

- at the operating condition No. 2 (see Figure 8) and No. $3\left(\mathrm{~T}_{\mathrm{HP}, \mathrm{IHX} \_ \text {outlet }}=32.0^{\circ} \mathrm{C}, \mathrm{P}_{\text {sn_inlet }}=38.44\right.$ bar, $\left.\mathrm{T}_{\mathrm{sn} \_ \text {inlet }}=10.4{ }^{\circ} \mathrm{C}, \dot{\mathrm{m}}_{\mathrm{mn}}=44.4 \mathrm{~g} \cdot \mathrm{s}^{-1}, \dot{\mathrm{m}}_{\mathrm{sn}}=26.2 \mathrm{~g} \cdot \mathrm{s}^{-1}\right)$, the pressure lift and total work recovery efficiency values of the vortex control are considerably lower;

- at the operating condition No. $4\left(\mathrm{~T}_{\mathrm{HP}, \mathrm{IHX} \_ \text {outlet }}=31.6{ }^{\circ} \mathrm{C}, \mathrm{P}_{\mathrm{sn} \_ \text {inlet }}=37.76 \mathrm{bar}, \mathrm{T}_{\mathrm{sn} \_ \text {inlet }}=6.5^{\circ} \mathrm{C}, \dot{\mathrm{m}}_{\mathrm{mn}}\right.$ $\left.=42.1 \mathrm{~g} \cdot \mathrm{s}^{-1}, \dot{\mathrm{m}}_{\mathrm{sn}}=22.4 \mathrm{~g} \cdot \mathrm{s}^{-1}\right)$, the vortex control performs similarly.

From the aforementioned outcomes it could be concluded that, at the present time, the vortex-based capacity control can at best equal the performance of the expansion valve-based control, but additional research efforts could change the situation.

\subsection{Vortex-based capacity control vs. needle-based capacity control vs. expansion valve-based capacity control}

The experimental work by Zhu and Elbel (2020) also brought to light that the needle control features the best performance among the three control strategies mentioned above as the gas cooler and evaporator air temperature are equal to $35{ }^{\circ} \mathrm{C}$ and $27{ }^{\circ} \mathrm{C}$ and $45{ }^{\circ} \mathrm{C}$ and $17{ }^{\circ} \mathrm{C}$, respectively. As presented in Figure 9, in fact, the vortex control has an optimal capacity and COP of $5.0 \%$ and $4.0 \%$ respectively, lower than the optimum values achieved with needle control. Furthermore, these differences were found to be more relevant at off-design operating conditions.

\section{Conclusions and future developments}

The crucial importance of the vapour-compression refrigeration, air conditioning and heat pump sector clashes with the imperative need for a sustainable future. Two-phase ejectors are believed to become a driving force in climate change mitigation within this sector. However, the energy (and environmental) benefits deriving from the application of these devices strongly depends on their performance at off-design operations. This means that an effective capacity control strategy of the ejector needs to be properly implemented in order to become highly performing solutions.

In this work, an extensive review on today's most widely used capacity control mechanisms for twophase ejectors, i.e. needle-based capacity control method, multi-ejector arrangement and vortexbased capacity control mechanism, has been carried out. It can be concluded that: 
- nowadays multi-ejector concept dominates the large- and medium-scale transcritical R744 applications. However, it is still unknown whether needle-based ejectors (and vortex ejectors) can be competitive (or even better) or not in this sector. Unlike the multi-ejector arrangement, in fact, neither the vortex ejectors nor the needle-based ejectors feature limitations in terms of size;

- although many experimental studies regarding needle-based ejectors are currently offered in the literature, no field measurements from real applications are available to the best of the authors' knowledge;

- vortex ejectors are still under investigation on a laboratory scale, being currently in their infancy. The first results have highlighted that this solution performs similarly to or slightly worse than the needle-based ejector. However, it seems that the former should be preferable to the ejectors including a needle, since the former is less vulnerable to clogging (being the flow control attained without changing the flow area), less complex and (potentially) less costly. Furthermore, the performance of the vortex ejectors could be further enhanced by improving the vortex generator, e.g. by having multiple tangential inlets, different tangential inlet and vortex chamber inner diameters;

- the energy improvements achievable with the aid of the vortex ejector should also be evaluated under low-temperature operating conditions.

A dramatic lack of an appropriate capacity control method for small-capacity units, such as light commercial refrigeration, automotive air conditioning, residential air conditioning units, has been enlightened, since they require a simpler low cost control mechanism compared to medium- and large-scale systems. Furthermore, the need to keep the ejector free of clogging is a challenge to overcome for the adoption of ejectors in small-capacity applications. At present, taking into account the low cost, the simplicity and the negligible difference in performance, series expansion valve control should be preferred to both the needle-based ejector and the vortex ejector control mechanisms in these units. However, the implementation of a much more effective capacity control method (i.e. a new mechanism and/or the enhancement of the two mentioned above) is urgent and mandatory so as to lead one of the most important sectors to take a new and sustainable growth path.

\section{Acknowledgement}

The research leading to these results has received funding from the European Union's Horizon 2020 research and innovation programme under the Marie Skłodowska-Curie grant agreement No 844924 (Project: $\mathrm{ECO}_{2}$-RAPJECT).

The accepted manuscript can be freely downloaded at: https://paridegullo.academia.edu/research 


\section{Nomenclature}

Symbols, abbreviations and subscripts/superscripts

$\begin{array}{ll}\text { AC } & \text { Air conditioning } \\ \text { CFD } & \text { Computational fluid dynamics } \\ \text { COP } & \text { Coefficient of performance }[-] \\ \text { CSPF } & \text { Cooling seasonal performance factor }[-] \\ \text { EER } & \text { Energy efficiency ratio [-] } \\ \text { evap } & \text { Evaporator } \\ \text { gc } & \text { Gas cooler } \\ \text { GHG } & \text { Greenhouse gas } \\ \text { HFC } & \text { Hydrofluorocarbons } \\ \text { HP } & \text { High pressure } \\ \text { IHX } & \text { Internal heat exchanger } \\ \dot{\mathrm{m}} & \text { Mass flow rate }\left[\mathrm{kg} \cdot \mathrm{s}^{-1} \text { ] }\right. \\ \text { MAC } & \text { Mobile air conditioning } \\ \text { mn } & \text { Motive nozzle } \\ \text { P } & \text { Pressure [bar, } \mathrm{kPa} \text { or MPa] } \\ \text { PID } & \text { Proportional-integral-derivative } \\ \text { PRR } & \text { Pressure recovery ratio [\%] } \\ \dot{\mathrm{Q}} & \text { Capacity [kW] } \\ \text { RACHP } & \text { Refrigeration, air conditioning and heat pump } \\ \text { sn } & \text { Suction nozzle } \\ \text { T } & \left.\text { Temperature [ }{ }^{\circ} \mathrm{C}\right]\end{array}$




\section{References}

- Aidoun, Z., Ameur, K., Falsafioon, M., Badache, M., 2019. Current Advances in Ejector Modeling, Experimentation and Applications for Refrigeration and Heat Pumps. Part 2: TwoPhase Ejectors. Inventions 4(1), 16. DOI: 10.3390/inventions4010016

- Banasiak, K., Hafner, A., Kriezi, E.E., Madsen, K.B., Birkelund, M., Fredslund, K., Olsson, R., 2015. Development and performance mapping of a multi-ejector expansion work recovery pack for R744 vapour compression units. International Journal of Refrigeration 57, 265-276. DOI: 10.1016/j.jijrefrig.2015.05.016

- Banasiak, K., Hafner, A., Haddal, O., Eikevik, T., 2014. Test facility for a multiejector R744 refrigeration system. In: Proceedings of the $11^{\text {th }}$ IIR Gustav Lorentzen Conference on Natural Refrigerants, $31^{\text {st }}$ August - $2^{\text {nd }}$ September; Hangzhou, China. ID: 70.

- Besagni, G., Mereu, R., Inzoli, F., 2016. Ejector refrigeration: A comprehensive review. Renewable and Sustainable Energy Reviews 53, 373-407. DOI: 10.1016/j.rser.2015.08.059

- Besagni, G., 2019. Ejectors on the cutting edge: The past, the present and the perspective. Energy 170, 998-1003. DOI: 10.1016/j.energy.2018.12.214

- Blust, S., Singh, S., Hafner, A., Banasiak, K., Nekså, P., 2018. Environment-friendly refrigeration packs for Indian supermarkets: experimental investigation of energy performance of a multiejector-driven R744 integrated compressor rack. In: Proceedings of the $13^{\text {th }}$ IIR Gustav Lorentzen Conference on Natural Refrigerants, $18^{\text {th }}-20^{\text {th }}$ June; Valencia, Spain. ID: 1136.

- Bodys, J., Smolka, J., Palacz, M., Haida, M., Banasiak, K., Nowak, A.J., Hafner, A., 2016. Performance of fixed geometry ejectors with a swirl motion installed in a multi-ejector module of a $\mathrm{CO}_{2}$ refrigeration system. Energy 117, 620-631. DOI: 10.1016/j.energy.2016.07.037

- Boccardi, G., Botticella, F., Lillo, G., Mastrullo, R., Mauro, A.W., Trinchieri, R., 2017. Experimental investigation on the performance of a transcritical $\mathrm{CO}_{2}$ heat pump with multiejector expansion system. International Journal of Refrigeration 82, 389-400. DOI: 10.1016/j.ijrefrig.2017.06.013

- Boccardi, G., Botticella, F., Lillo, G., Mastrullo, R., Mauro, A.W., Trinchieri, R., 2016. Thermodynamic Analysis of a Multi-Ejector, $\mathrm{CO}_{2}$, Air-To-Water Heat Pump System. Energy Procedia 101, 846-853. DOI: $10.1016 /$ j.egypro.2016.11.107

- Chen, J., Yu, J., Qian, S., 2019. Subcooling control method for the adjustable ejector in the direct expansion solar assisted ejector-compression heat pump water heater. Applied Thermal Engineering 148, 662-673. DOI: $10.1016 / \mathrm{j}$.applthermaleng.2018.11.086

- Chen, X., Omer, S., Worall, M., Riffat, S., 2013. Recent developments in ejector refrigeration technologies. Renewable and Sustainable Energy Reviews 19, 629-651. DOI: 10.1016/j.rser.2012.11.028

- Elbel, S., Lawrence, N., 2016. Review of recent developments in advanced ejector technology. International Journal of Refrigeration 62, 1-18. DOI: 10.1016/j.ijrefrig.2015.10.031

- Elbel, S., Hrnjak, P., 2008. Experimental validation of a prototype ejector design to reduce throttling losses encountered in transcritical R744 system operate. International Journal of Refrigeration 31, 411-422. DOI: 10.1016/j.ijrefrig.2007.07.013

- Elbel, S., 2011. Historical and present developments of ejector refrigeration systems with emphasis on transcritical carbon dioxide air-conditioning applications. International Journal of Refrigeration 34(7), 1545-1561. DOI: 10.1016/j.ijrefrig.2010.11.011

- European Commission, 2019. 2030 climate \& energy framework. - Available at: $<$ https://ec.europa.eu/clima/policies/strategies/2030_en> [accessed 11.02.2020]. 
- Ferrarese, T., Zanco, A., Del Col, D., 2018. Experimental measurements on the effect of a modulating ejector in a transcritical $\mathrm{CO}_{2}$ system. In: Proceedings of the $13^{\text {th }}$ IIR Gustav Lorentzen Conference on Natural Refrigerants, $18^{\text {th }}-20^{\text {th }}$ June; Valencia, Spain. ID: 1365.

- $\quad$ Fredslund, K., Kriezi, E. E., Madsen, K. B., Birkelund, M., Olsson, R., 2016. $\mathrm{CO}_{2}$ installations with a multi ejector for supermarkets, case studies from various locations. In: Proceedings of the $12^{\text {th }}$ IIR Gustav Lorentzen Natural Working Fluids Conference, $21^{\text {st }}-24^{\text {th }}$ August; Edinburgh, UK. ID: 1105.

- Girotto, S., 2017. Improved transcritical $\mathrm{CO}_{2}$ refrigeration systems for warm climates. In: Proceedings of the $7^{\text {th }}$ IIR Ammonia and $\mathrm{CO}_{2}$ Refrigeration Technologies Conference, $11^{\text {th }}-13^{\text {th }}$ May; Ohrid, Macedonia.

- Gullo, P., 2019. Innovative fully integrated transcritical R744 refrigeration systems for HFC-free future of supermarkets in warm and hot climates. International Journal of Refrigeration 108, 283310. DOI: $10.1016 /$ j.ijrefrig.2019.09.001

- Gullo, P., Hafner, A., Banasiak, K., 2019. Thermodynamic Performance Investigation of Commercial R744 Booster Refrigeration Plants Based on Advanced Exergy Analysis. Energies 12(3), 354. DOI: $10.3390 /$ en12030354

- Gullo, P., Hafner, A., Banasiak, K., 2018c. Transcritical R744 refrigeration systems for supermarket applications: Current status and future perspectives. International Journal of Refrigeration 93, 269-310. DOI: 10.1016/j.ijrefrig.2018.07.001

- Gullo, P., Tsamos, K.M., Hafner, A., Banasiak, K., Ge, Y.T., Tassou, S.A., 2018b. Crossing $\mathrm{CO}_{2}$ equator with the aid of multi-ejector concept: A comprehensive energy and environmental comparative study. Energy 164, 236-263. DOI: 10.1016/j.energy.2018.08.205

- Gullo, P., Purohit, N., Dasgupta, M.S., Hafner, A., 2018a. Energetic and environmental performance evaluation of a R774 multi-ejector enhanced parallel compression system in high temperature locations. In: In: Proceedings of the $5^{\text {th }}$ IIR Conference on Sustainability and Cold Chain, $6^{\text {th }}-8^{\text {th }}$ April; Beijing, China.

- Gullo, P., Hafner, A., Cortella, G., 2017. Multi-ejector R744 booster refrigerating plant and air conditioning system integration - A theoretical evaluation of energy benefits for supermarket applications. International Journal of Refrigeration 75, 164-176. DOI: 10.1016/j.ijrefrig.2016.12.009

- Hafner, A., Banasiak, K., Fredslund, K., Girotto, S., Smolka, J., 2016. R744 ejector system case: Italian supermarket, Spiazzo. In: Proceedings of the $12^{\text {th }}$ IIR Gustav Lorentzen Natural Working Fluids Conference, $21^{\text {st }}-24^{\text {th }}$ August; Edinburgh, UK. ID: 1078.

- Hafner, A., Schönenberger, J., Banasiak, K., Girotto, S., 2014b. R744 ejector supported parallel vapour compression system. In: Proceedings of the $3^{\text {rd }}$ IIR International Conference on Sustainability and Cold Chain, $23^{\text {rd }}-25^{\text {th }}$ June; London, UK. ID: 129.

- Hafner, A., Försterling, S., Banasiak, K., 2014a. Multi-ejector concept for R-744 supermarket refrigeration. International Journal of Refrigeration 43, 1-13. DOI: 10.1016/j.ijrefrig.2013.10.015

- Hafner, A., Poppi, S., Nekså, P., Minetto, S., Eikevik, T.M., 2012. Development of commercial refrigeration systems with heat recovery for supermarket building. In: Proceedings of the $10^{\text {th }}$ IIR Gustav Lorentzen Conference on Natural Refrigerants, $25^{\text {th }}-27^{\text {th }}$ June; Delft, The Netherlands. ID: 192.

- Haida, M., Banasiak, K., Smolka, J., Hafner, A., Eikevik, T. M., 2016. Experimental analysis of the R744 vapour compression rack equipped with the multi-ejector expansion work recovery module. International Journal of Refrigeration 64, 93-107. DOI: 10.1016/j.ijrefrig.2016.01.017

- He, Y., Deng, J., Li, Y., Ma, L., 2019. A numerical contrast on the adjustable and fixed transcritical $\mathrm{CO}_{2}$ ejector using exergy flux distribution analysis. Energy Conversion and Management 196, 729-738. DOI: 10.1016/j.enconman.2019.06.031 
- He, Y., Deng, J., Yang, F., Zhang, Z., 2017b. An optimal multivariable controller for transcritical $\mathrm{CO}_{2}$ refrigeration cycle with an adjustable ejector. Energy Conversion and Management 142, 466-476. DOI: 10.1016/j.enconman.2017.03.070

- He, Y., Deng, J., Zheng, L., Zhang, Z., 2017a. Performance optimization of a transcritical $\mathrm{CO}_{2}$ refrigeration system using a controlled ejector. International Journal of Refrigeration 75, 250261. DOI: $10.1016 /$ j.ijrefrig.2016.12.015

- Hou, W., Wang, L., Yan, J., Wang, L., 2017. Simulation on the performance of ejector in a parallel hybrid ejector-based refrigerator-freezer cooling cycle. Energy Conversion and Management 143(1), 440-447. DOI: 10.1016/j.enconman.2017.04.030

- Hu, J., Shi, J., Liang, Y., Yang, Z., Chen, J., 2014. Numerical and experimental investigation on nozzle parameters for R410A ejector air conditioning system. International Journal of Refrigeration 40, 338-346. DOI: 10.1016/j.ijrefrig.2013.12.008

- IIR, 2019. $38^{\text {th }}$ Informatory Note on Refrigeration Technologies - The Role of Refrigeration in the Global Economy. - Available at: $\langle$ http://www.iifiir.org/userfiles/file/publications/notes/NoteTech_38_EN.pdf $>\quad$ [accessed 11.02.2020].

- $\quad$ Isaac, M., van Vuuren, D. P., 2009. Modeling global residential sector energy demand for heating and air conditioning in the context of climate change. Energy Policy 37(2), 507-521. DOI: 10.1016/j.enpol.2008.09.051

- Jeon, Y., Kim, D., Jung, J., Jang, D.S., Kim, Y., 2018. Comparative performance evaluation of conventional and condenser outlet split ejector-based domestic refrigerator-freezers using R600a. Energy 161, 1085-1095. DOI: 10.1016/j.energy.2018.08.007

- Jeon, Y., Kim, S., Kim, D., Chung, H.J., Kim, Y., 2017b. Performance characteristics of an R600a household refrigeration cycle with a modified two-phase ejector for various ejector geometries and operating conditions. Applied Energy 205, 1059-1067. DOI: 10.1016/j.apenergy.2017.08.148

- Jeon, Y., Jung, J., Kim, D., Kim, S., Kim, Y., 2017a. Effects of ejector geometries on performance of ejector-expansion R410A air conditioner considering cooling seasonal performance factor. Applied Energy 205, 761-768. DOI: 10.1016/j.apenergy.2017.08.059

- Kim, S., Jeon, Y., Chung, H.J., Kim, Y., 2018. Performance optimization of an R410A airconditioner with a dual evaporator ejector cycle based on cooling seasonal performance factor. Applied Thermal Engineering 131, 988-997. DOI: 10.1016/j.applthermaleng.2017.12.012

- Lawrence, N., Elbel, S., 2019. Experimental investigation on control methods and strategies for off-design operation of the transcritical R744 two-phase ejector cycle. International Journal of Refrigeration 106, 570-582. DOI: 10.1016/j.ijrefrig.2019.04.020

- Lawrence, N., Elbel, S., 2016d. Numerical modelling of the off-design performance of a transcritical $\mathrm{CO}_{2}$ two-phase ejector cycle. In: Proceedings of the $13^{\text {th }}$ IIR Gustav Lorentzen Conference on Natural Refrigerants, $18^{\text {th }}-20^{\text {th }}$ June; Valencia, Spain. ID: 1084.

- Lawrence, N., Elbel, S., 2016c. Experimental investigation of control strategies for off-design operation of a transcritical $\mathrm{CO}_{2}$ two-phase ejector refrigeration system for the cold chain. In: Proceedings of the $4^{\text {th }}$ IIR International Conference on Sustainability and the Cold Chain, $7^{\text {th }}$ $9^{\text {th }}$ April; Auckland, New Zealand.

- Lawrence, N., Elbel, S., 2016b. Experimental comparison of the performance of a $\mathrm{CO}_{2}$ ejector cycle for transcritical and subcritical operation. In: Proceedings of the $12^{\text {th }}$ IIR Gustav Lorentzen Natural Working Fluids Conference, $21^{\text {st }}-24^{\text {th }}$ August; Edinburgh, UK. ID: 1085.

- $\quad$ Lawrence, N., Elbel, S., 2016a. Experimental study on control methods for transcritical $\mathrm{CO}_{2}$ twophase ejector systems at off-design conditions. In: Proceedings of the $12^{\text {th }}$ IIR Gustav Lorentzen Natural Working Fluids Conference, $21^{\text {st }}-24^{\text {th }}$ August; Edinburgh, UK. ID: 1083. 
- Lawrence, N., 2016. Experimental and Numerical Investigation of the Design and Control of Vapor-Compression Systems with Integration of two-Phase Ejectors for Performance Enhancement through Expansion Work Recovery. Ph.D. dissertation; University of Illinois Urbana-Champaign, Urbana and Champaign, USA. - Available at: $<$ https://www.ideals.illinois.edu/handle/2142/95306> [accessed 11.02.2020].

- Lin, C., Cai, W., Li, Y., Yan, J., Hu, Y., Giridharan, K., 2013b. Numerical investigation of geometry parameters for pressure recovery of an adjustable ejector in multi-evaporator refrigeration system. Applied Thermal Engineering 61(2), 649-656. DOI: 10.1016/j.applthermaleng.2013.08.033

- Lin, C., Li, Y., Cai, W., Yan, J., Hu, Y., 2013a. Experimental investigation of the adjustable ejector in a multi-evaporator refrigeration system. Applied Thermal Engineering 61(2), 2-10. DOI: 10.1016/j.applthermaleng.2013.07.045

- Lin, C., Cai, W., Li, Y., Yan, J., Hu, Y., 2012. The characteristics of pressure recovery in an adjustable ejector multi-evaporator refrigeration system. Energy 46(1), 148-155. DOI: 10.1016/j.energy.2012.09.007

- Liu, F., Groll, E.A., Ren, J., 2016. Comprehensive experimental performance analyses of an ejector expansion transcritical $\mathrm{CO}_{2}$ system. Applied Thermal Engineering 98, 1061-1069. DOI: 10.1016/j.applthermaleng.2015.12.017

- Liu, F., Groll, E.A., Li, D., 2012c. Modeling study of an ejector expansion residential $\mathrm{CO}_{2}$ air conditioning system. Energy and Buildings 53, 127-136. DOI: 10.1016/j.enbuild.2012.07.008

- Liu, F., Groll, E.A., Li, Y., 2012b. Investigation on performance of variable geometry ejectors for $\mathrm{CO}_{2}$ refrigeration cycles. Energy 45, 829-839. DOI: 10.1016/j.energy.2012.07.008

- Liu, F., Li, Y., Groll, E.A., 2012a. Performance enhancement of $\mathrm{CO}_{2}$ air conditioner with a controllable ejector. International Journal of Refrigeration 35(6), 1604-1616. DOI: 10.1016/j.ijrefrig.2012.05.005

- Liu, F., Groll, E.A., 2013. Study of ejector efficiencies in refrigeration cycles. Applied Thermal Engineering 52(2), 360-370. DOI: 10.1016/j.applthermaleng.2012.12.001

- Liu, F., Groll, E.A., 2008. Analysis of a Two Phase Flow Ejector For Transcritical $\mathrm{CO}_{2}$ Cycle. In: Proceedings of the $12^{\text {th }}$ International Refrigeration and Air Conditioning Conference at Purdue, $14^{\text {th }}-17^{\text {th }}$ July; West Lafayette, USA. ID: 924.

- Lucas, C., Koehler, J., 2012. Experimental investigation of the COP improvement of a refrigeration cycle by use of an ejector. International Journal of Refrigeration 35(6), 1595-1603. DOI: $10.1016 /$ j.ijrefrig.2012.05.010

- Madsen, K.B., Kriezi, E.K., 2018. Financial aspects of ejector solutions in supermarket and smaller industrial systems. In Proceedings of the $13^{\text {th }}$ IIR Gustav Lorentzen Conference on Natural Refrigerants, $18^{\text {th }}-20^{\text {th }}$ June; Valencia, Spain. ID: 1403.

- Matthiesen, O., Madsen, K., Mikhailov, A., 2010. Evolution of $\mathrm{CO}_{2}$ systems design based on practical experiences from supermarket installations in Northern Europe. In: Proceedings of the $9^{\text {th }}$ IIR Gustav Lorentzen conference on natural working fluids, $12^{\text {th }}-14^{\text {th }}$ April; Sydney, Australia. ID: 81.

- Peters, T., 2018. A Cool World - Defining the Energy Conundrum of 'Cooling for All. Available $\quad$ at: $\quad<$ https://www.birmingham.ac.uk/Documents/collegeeps/energy/Publications/2018-clean-cold-report.pdf $>$ [accessed 11.02.2020].

- Poolman, C., Verma, P., Lee, K., 2018. Modulating two phase ejectors in transport refrigeration. In: Proceedings of the $13^{\text {th }}$ IIR Gustav Lorentzen Conference on Natural Refrigerants, $18^{\text {th }}-20^{\text {th }}$ June; Valencia, Spain. ID: 1396.

- Ren, L.Q., Guo, X.M., Guo, X.W., Li, T.L., 2014. Experimental Study on Performance of Twophase Ejector refrigeration Cycle system with Two-throat Nozzle. In: Proceedings of the $15^{\text {th }}$ 
International Refrigeration and Air Conditioning Conference at Purdue, $14^{\text {th }}-17^{\text {th }}$ July; West Lafayette, USA. ID: 1472.

- $\quad$ Ringstad, K., Allouche, Y., Gullo, P., Banasiak, K., Hafner, A., 2019. $\mathrm{CO}_{2}$ ejector modelling using CFD: current status. In: Proceedings of the $25^{\text {th }}$ IIR International Congress of Refrigeration, $24^{\text {th }}-30^{\text {th }}$ August; Montreal, Canada. ID: 1870.

- Sarkar, J., 2012. Ejector enhanced vapor compression refrigeration and heat pump systems - A review. Renewable and Sustainable Energy Reviews 16(9), 6647-6659. DOI: 10.1016/j.rser.2012.08.007

- Schönenberger, J., Hafner, A., Banasiak, K., Girotto, S., 2014. Experience with ejectors implemented in a R744 booster system operating in a supermarket. In: Proceedings of the $11^{\text {th }}$ IIR Gustav Lorentzen Conference on Natural Refrigerants, $31^{\text {st }}$ August $-2^{\text {nd }}$ September; Hangzhou, China. ID: 19.

- Singh, S., Amshith, R., Prakash, M.M., Banasiak, K., Hafner, A., Nekså, P., 2018b. Performance Investigation of a Multi-ejector R744 Heat Pump. In: Proceedings of the $13^{\text {th }}$ IIR Gustav Lorentzen Conference on Natural Refrigerants, $18^{\text {th }}-20^{\text {th }}$ June; Valencia, Spain. ID: 1287.

- Singh, S., Hafner, A., Banasiak, K., Maiya, P., Nekså, P., 2018a. Experimental evaluation of multi-ejector based $\mathrm{CO}_{2}$ cooling system for supermarkets in tropical zones. In: Proceedings of the $17^{\text {th }}$ International Refrigeration and Air Conditioning Conference at Purdue, $9^{\text {th }}-12^{\text {th }}$ July; West Lafayette, USA.

- Smolka, J., Palacz, M., Bodys, J., Banasiak, K., Fic, A., Bulinski, Z., Nowak, A. J., Hafner, A., 2016. Performance comparison of fixed- and controllable-geometry ejectors in a $\mathrm{CO}_{2}$ refrigeration system. International Journal of Refrigeration 65, 172-182. DOI: $\underline{10.1016 / j . j \text { ijrefrig.2016.01.025 }}$

- Sumeru, K., Nasution, H., Ani, F.N., 2012, A review on two-phase ejector as an expansion device in vapor compression refrigeration cycle. Renewable and Sustainable Energy Reviews 16(7), 4927-4937. DOI: $10.1016 /$ j.rser.2012.04.058

- Tashtoush, B.M., Al-Nimr, M.A., Khasawneh, M.A., 2019. A comprehensive review of ejector design, performance, and applications. Applied Energy 240, 138-172. DOI: 10.1016/j.apenergy.2019.01.185

- Xu, X.X., Chen, G.M., Tang, L.M., Zhu, Z.J., 2012. Experimental investigation on performance of transcritical $\mathrm{CO}_{2}$ heat pump system with ejector under optimum high-side pressure. Energy 44(1), 870-877. DOI: 10.1016/j.energy.2012.04.062

- Zheng, L., Deng, J., 2017. Research on $\mathrm{CO}_{2}$ ejector component efficiencies by experiment measurement and distributed-parameter modeling. Energy Conversion and Management 142, 244-256. DOI: 10.1016/j.enconman.2017.03.017

- Zheng, L., Deng, J., Zhang, Z., 2016. Dynamic simulation of an improved transcritical $\mathrm{CO}_{2}$ ejector expansion refrigeration cycle. Energy Conversion and Management 114, 278-289. DOI: 10.1016/j.enconman.2016.01.069

- Zheng, L., Deng, J., He, Y., 2015. A comparative study on regulation methods for transcritical $\mathrm{CO}_{2}$ ejector expansion refrigeration system. In: Proceedings of the $24^{\text {th }}$ IIR International Congress of Refrigeration, $16^{\text {th }}-22^{\text {nd }}$ August; Yokohama, Japan. ID: 53.

- Zhu, J., Botticella, F., Elbel, S., 2018c. Experimental investigation and theoretical analysis of oil circulation rates in ejector cooling cycles. Energy 157, 718-733. DOI: 10.1016/j.energy.2018.05.152

- Zhu, J., Botticella, F., Elbel, S., 2018b. Measurement of oil in circulation in transcritical R744 systems using two-phase ejector. In: Proceedings of the $13^{\text {th }}$ IIR Gustav Lorentzen Conference on Natural Refrigerants, $18^{\text {th }}-20^{\text {th }}$ June; Valencia, Spain. ID: 1141.

- Zhu, J., Botticella, F., Elbel, S., 2018a. Oil Circulation Rate in Ejector Cooling Cycles. SAE Technical Paper 2018-01-0077. DOI:10.4271/2018-01-0077 
- Zhu, J., Elbel, S., 2020. Experimental investigation into the influence of vortex control on transcritical R744 ejector and cycle performance. Applied Thermal Engineering 164, 114418. DOI: $10.1016 /$ j.applthermaleng.2019.114418

- Zhu, J., Elbel, S., 2019. CFD Simulation of Vortex Flashing R134a Flows Expanded through Convergent-Divergent Nozzles. International Journal of Refrigeration 112, 56-68. DOI: 10.1016/j.ijrefrig.2019.12.005

- Zhu, J., Elbel, S., 2018g. CFD Simulation Of Vortex Flashing Flows In Convergent-Divergent Nozzles. In: Proceedings of the $17^{\text {th }}$ International Refrigeration and Air Conditioning Conference at Purdue, $9^{\text {th }}-12^{\text {th }}$ July; West Lafayette, USA. ID: 2147.

- Zhu, J., Elbel, S., 2018f. Measurement of static pressure profiles of vortex flashing R134a flow expanded through convergent-divergent nozzles. International Journal of Refrigeration 108, 258270. DOI: $10.1016 /$ j.ijrefrig.2019.08.023

- Zhu, J., Elbel, S., 2018e. Measurement Of Pressure Profile Of Vortex Flashing Flows In Convergent-Divergent Nozzles. In: Proceedings of the $17^{\text {th }}$ International Refrigeration and Air Conditioning Conference at Purdue, $9^{\text {th }}-12^{\text {th }}$ July; West Lafayette, USA. ID: 2414.

- Zhu, J., Elbel, S., 2018d. Experimental investigation of a novel expansion device control mechanism: Vortex control of initially subcooled flashing R134a flow expanded through convergent-divergent nozzles. International Journal of Refrigeration 85, 167-183. DOI: 10.1016/j.ijrefrig.2017.09.023

- Zhu, J., Elbel, S., 2018c. Application of vortex control to a transcritical R744 ejector cycle. In: Proceedings of the $5^{\text {th }}$ IIR Conference on Sustainability and the Cold Chain, $6^{\text {th }}-8^{\text {th }}$ April; Beijing, China. ID: 0005.

- Zhu, J., Elbel, S., 2018b. Vortex control for motive flow rate modulation of transcritical R744 ejector systems. In: Proceedings of the $13^{\text {th }}$ IIR Gustav Lorentzen Conference on Natural Refrigerants, $18^{\text {th }}-20^{\text {th }}$ June; Valencia, Spain. ID: 1143.

- Zhu, J., Elbel, S., 2018a. Application of Vortex Control to an Automotive Transcritical R744 Ejector Cycle. SAE Technicla Paper. DOI: 10.4271/2018-01-0060

- Zhu, J., Elbel, S., 2017. Influence of Nozzle Divergent Part Length and Throat diameter on Vortex Control of Initially Subcooled Flashing Flow. SAE International Journal of Passenger Cars - Mechanical Systems 10(1), 121-127. DOI: 10.4271/2017-01-0165

- Zhu, J., Elbel, S., 2016c. Modeling of Initially Subcooled Flashing Vortex Flow in the Nozzle for Possible Applications in the Control of Ejector Cooling Cycles. In: Proceedings of the $16^{\text {th }}$ International Refrigeration and Air Conditioning Conference, $11^{\text {th }}-14^{\text {th }} \mathrm{July}$; West Lafayette, USA. ID: 2368.

- Zhu, J., Elbel, S., 2016b. A New Control Mechanism for Two-Phase Ejector in Vapor Compressions Cycles Using Adjustable Motive Nozzle Inlet Vortex. In: Proceedings of the $16^{\text {th }}$ International Refrigeration and Air Conditioning Conference, $11^{\text {th }}-14^{\text {th }} \mathrm{July}$; West Lafayette, USA. ID: 2076.

- Zhu, J., Elbel, S., 2016a. A New Control Mechanism for Two-Phase Ejector in Vapor Compressions Cycles for Automotive Applications Using Adjustable Motive Nozzle Inlet Swirl. SAE International Journal of Passenger Cars - Mechanical Systems 9(1), 44-51. DOI: $\underline{10.4271 / 2016-01-0243}$ 
Figure 1. Schematic of the capacity control mechanisms for two-phase ejectors: (a) adjustable needle-based ejector, (b) multi-ejector arrangement and (c) expansion valve in series or parallel with ejector (Lawrence and Elbel, 2019).

(a) Adjustable position needle to control effective nozzle throat cross-sectional area

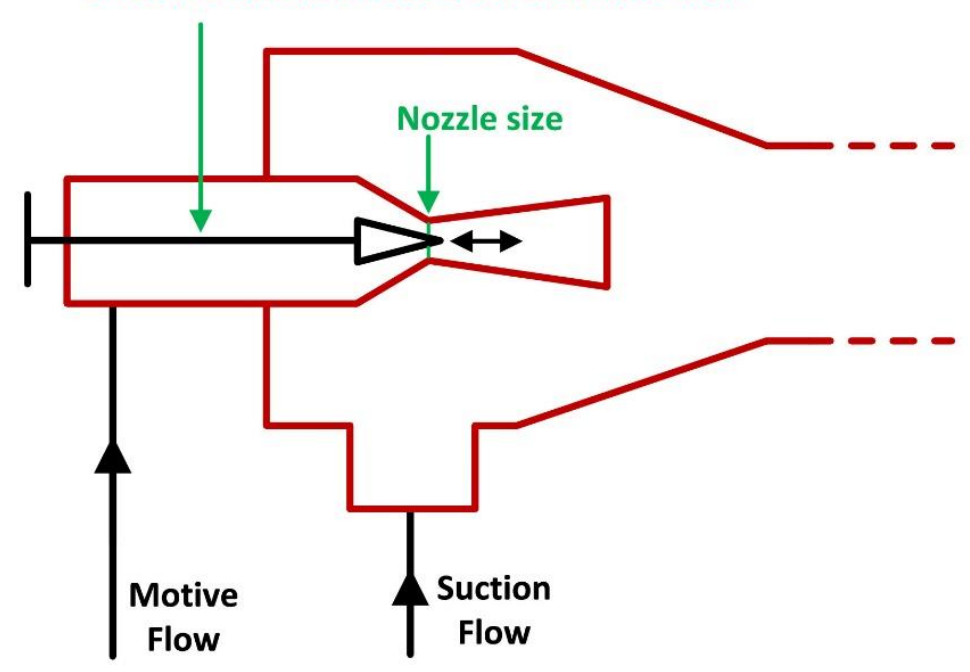

(b)

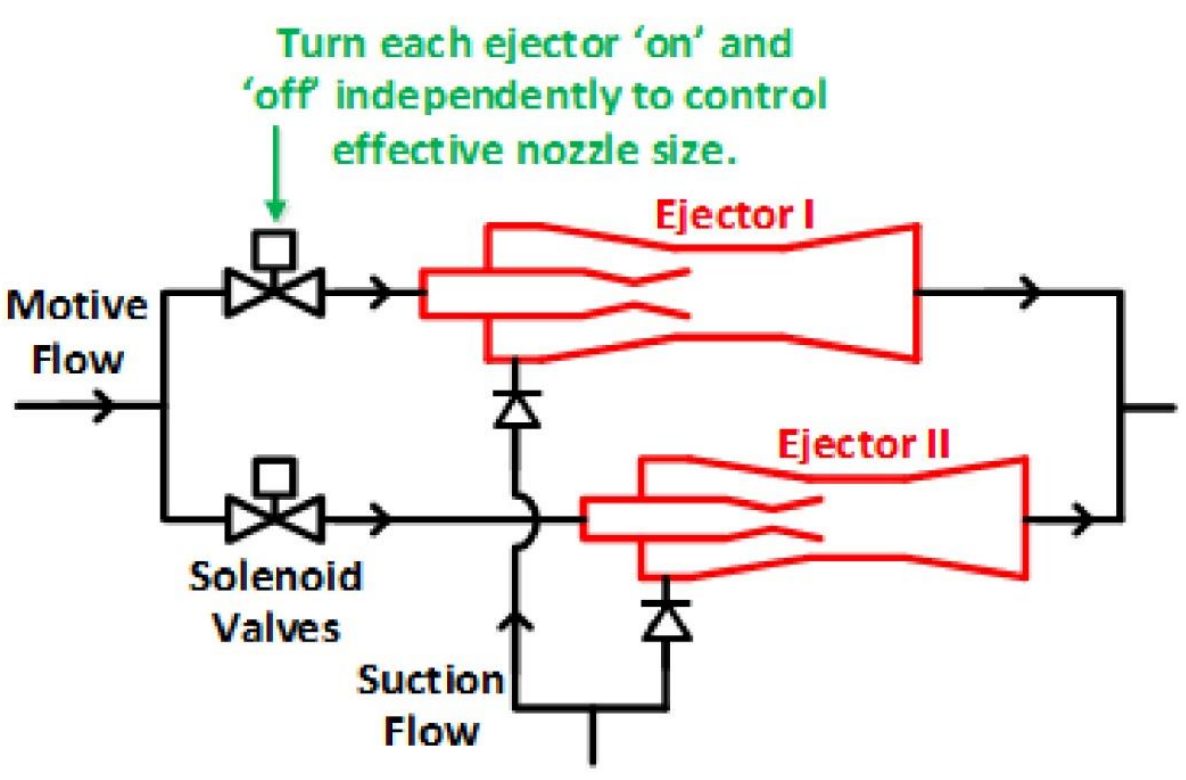

(c)

Parallel expansion valve to decrease gas cooler pressure

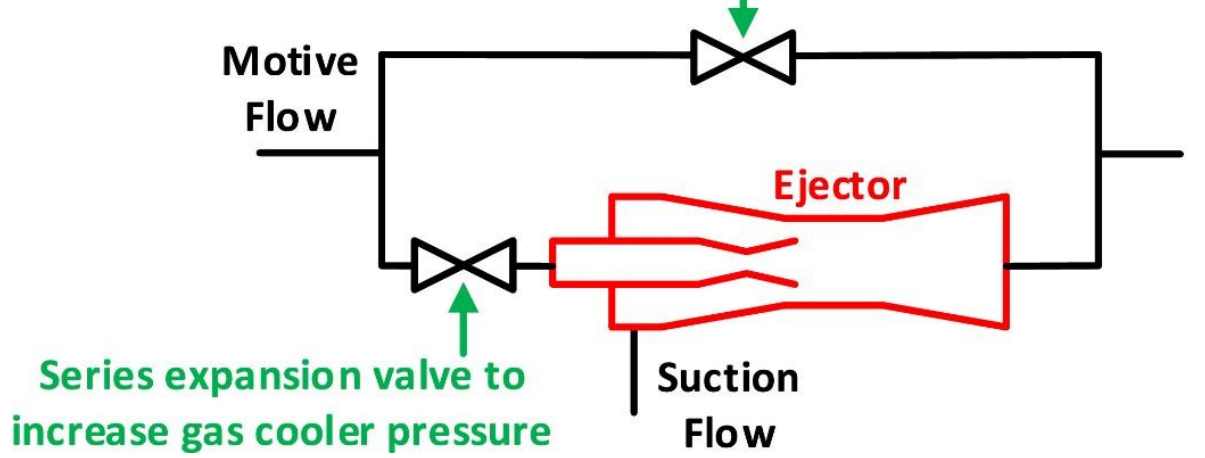

The accepted manuscript can be freely downloaded at: https://paridegullo.academia.edu/research 
Figure 2. Schematic of a passive ejector, vortex ejector and vortex ejector-based vapour-compression system (Zhu and Elbel, 2016a).

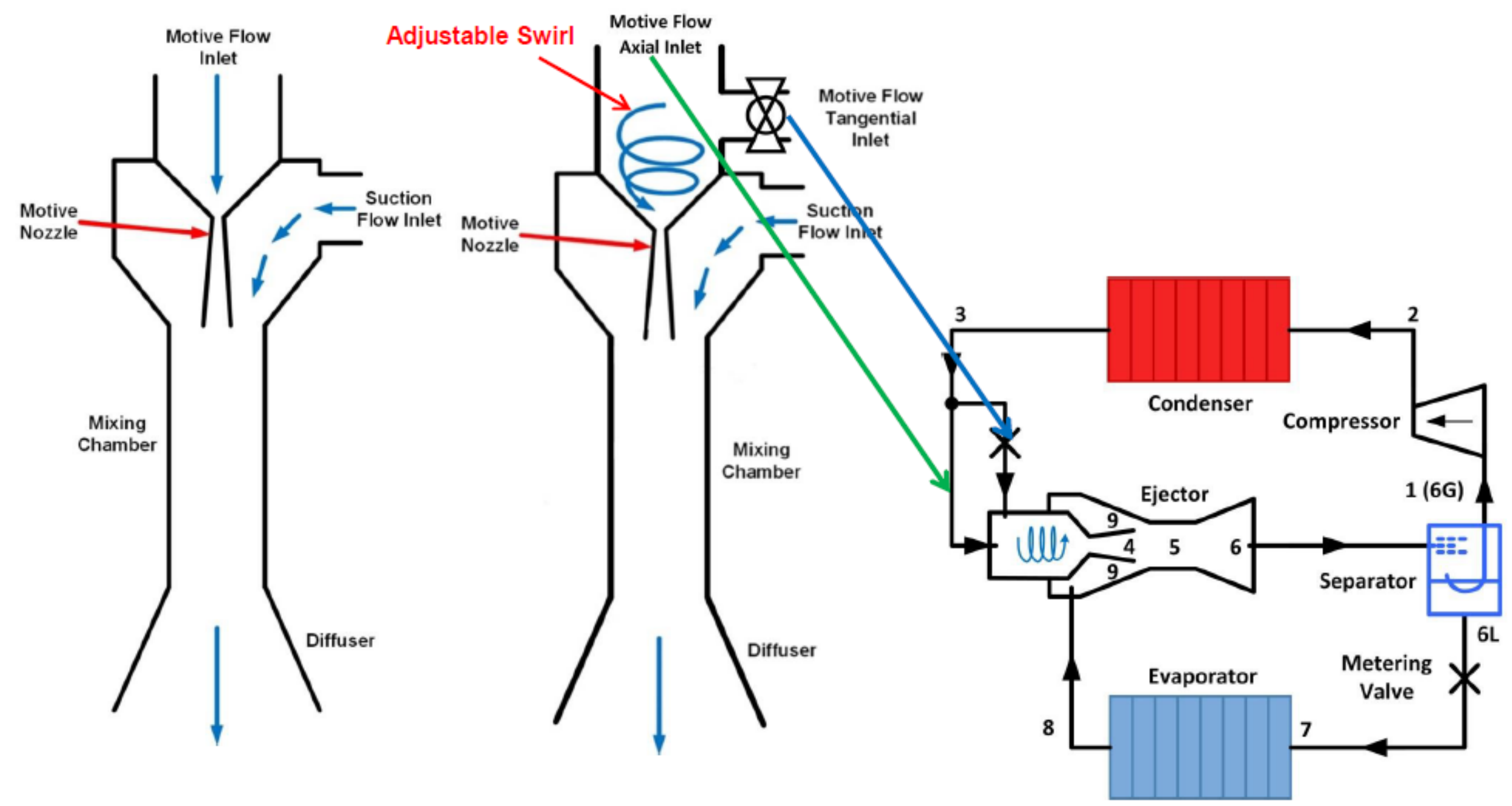


Figure 3. Schematic of the two-throat nozzle ejector (Ren et al., 2014).

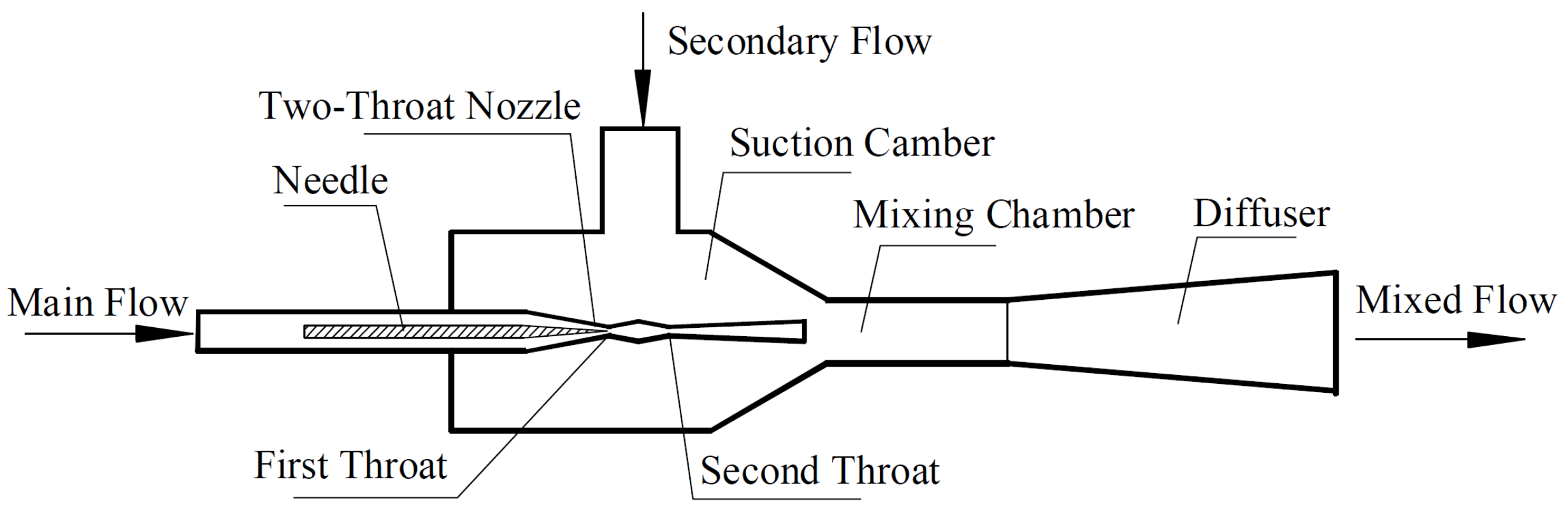

The accepted manuscript can be freely downloaded at: https://paridegullo.academia.edu/research 
Figure 4. Influence of the throat area of the nozzle on the system COP and the entrainment ratio (Ren et al., 2014).

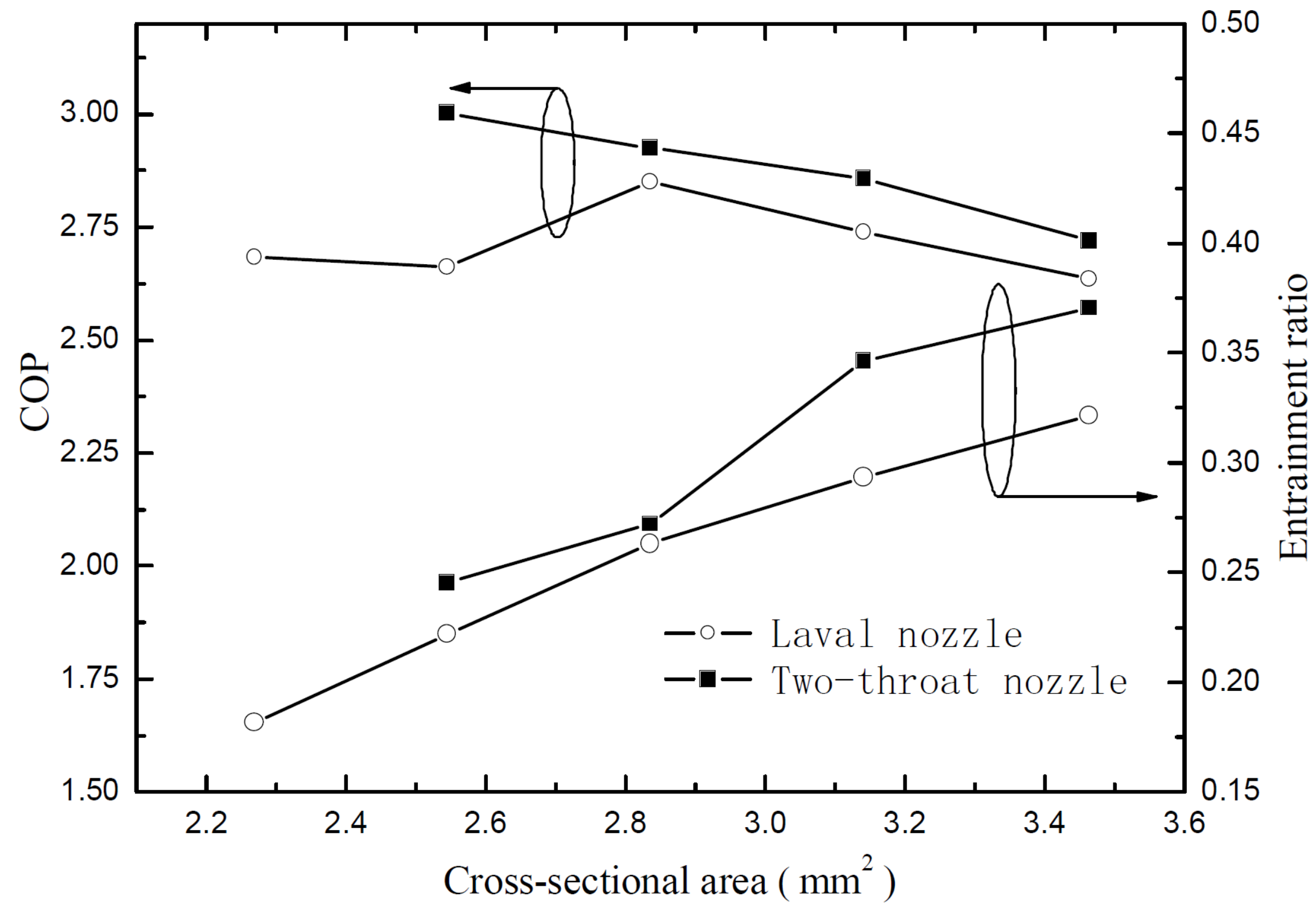

The accepted manuscript can be freely downloaded at: https://paridegullo.academia.edu/research 
Figure 5. Influence of the nozzle inlet vortex strength on the total mass flow rate through the nozzle at different constant inlet conditions (all data points for choked flow, vortex strength $\left.=\dot{\mathrm{m}}_{\text {tangential }} / \dot{\mathrm{m}}_{\text {total }}\right)($ Zhu and Elbel, 2016a).

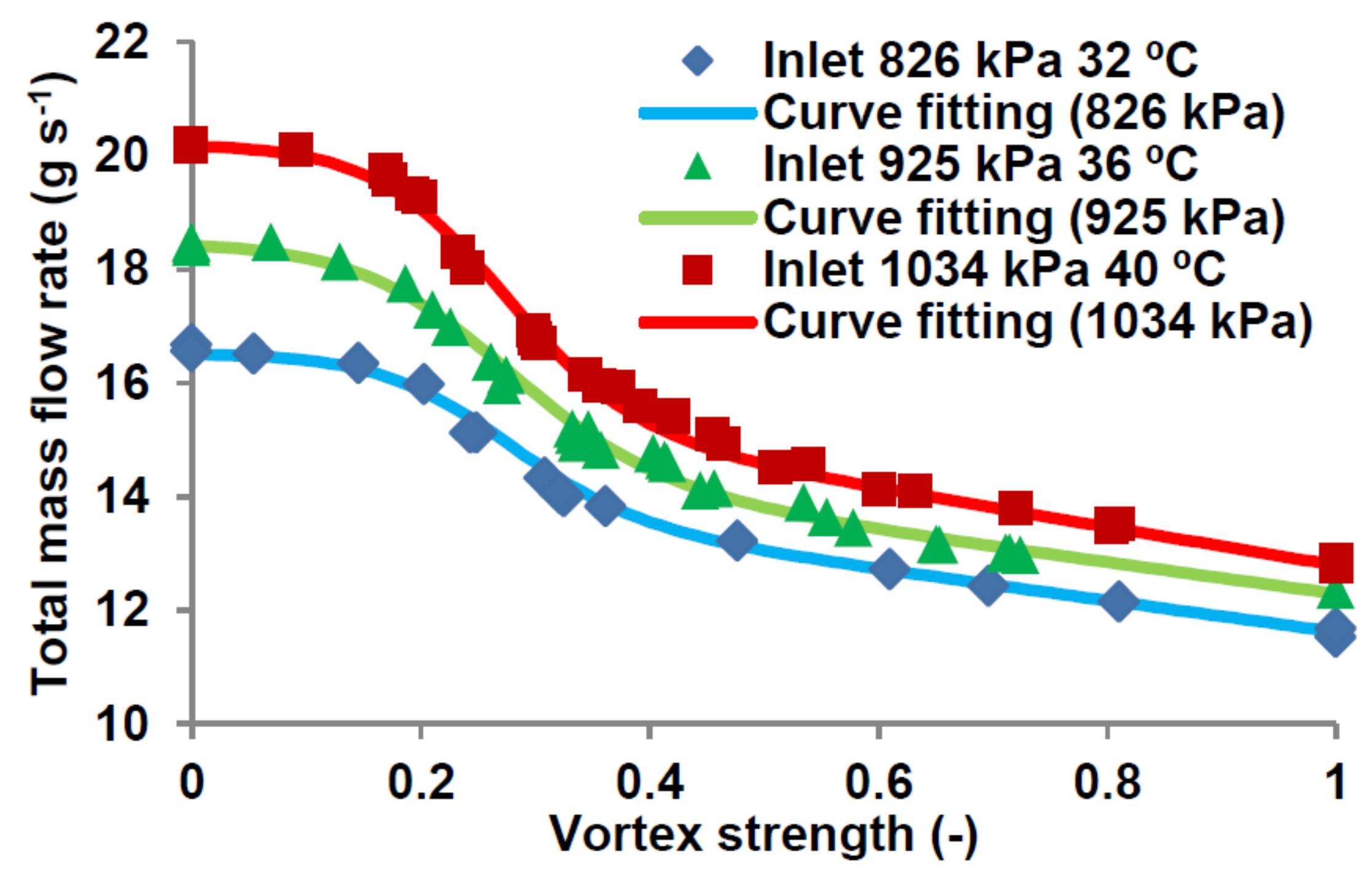


Figure 6. Effect of the ejector motive nozzle inlet vortex strength (vortex strength $=\dot{\mathrm{m}}_{\text {tangential }} / \dot{\mathrm{m}}_{\text {total }}$ ) on the ejector efficiency for MAC applications (Zhu and Elbel, 2018a).

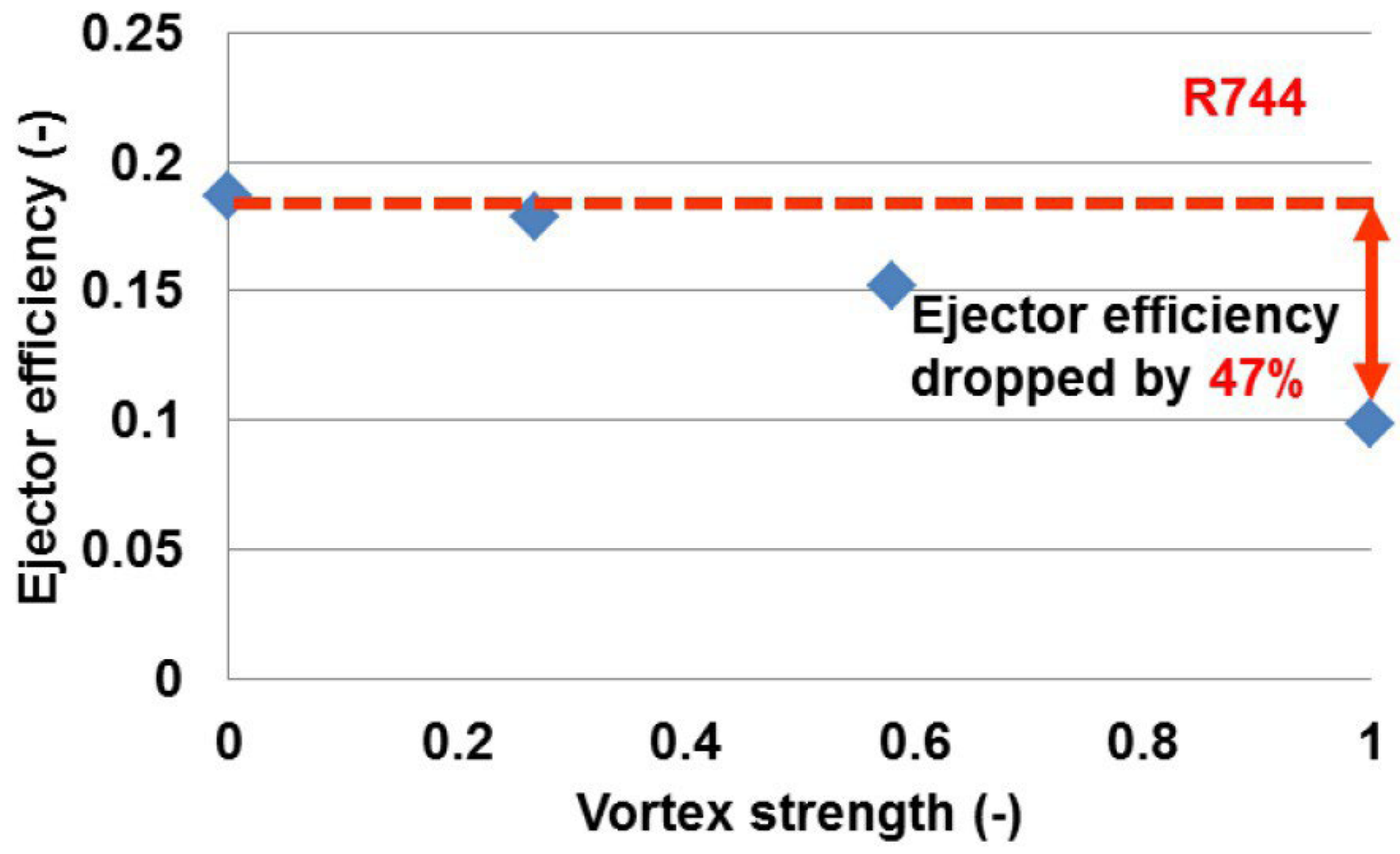


Figure 7. Comparison in terms of COP between the adjustable needle-based ejector control and the series expansion ejector control $\left(\mathrm{T}_{\text {air,evap_inlet }}=27\right.$ ${ }^{\circ} \mathrm{C}, \mathrm{T}_{\text {air,gc } \_ \text {inlet }}=35^{\circ} \mathrm{C}$, compressor rotational frequency $\left.=1200 \mathrm{~min}^{-1}\right)($ Lawrence and Elbel, 2019).

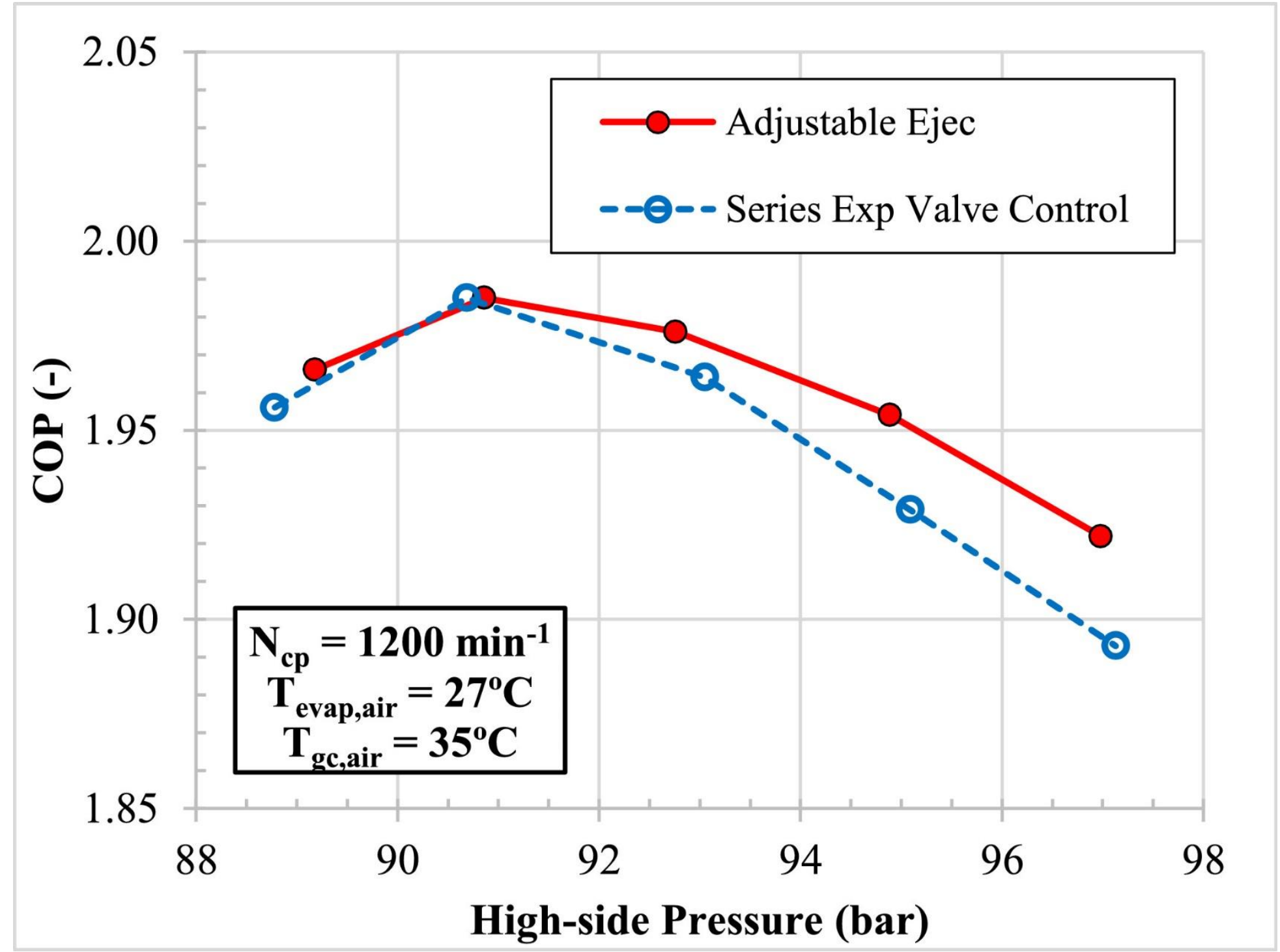

The accepted manuscript can be freely downloaded at: https://paridegullo.academia.edu/research 
Figure 8. Effect of the IHX high-side outlet pressure on (a) the pressure lift and (b) the total work recovery efficiency considering series expansion valve control and vortex control $\left(\mathrm{T}_{\mathrm{HP}, \mathrm{IHX} \text { _outlet }}=32.3\right.$ $\left.{ }^{\circ} \mathrm{C}, \mathrm{P}_{\text {sn_inlet }}=37.34 \mathrm{bar}, \mathrm{T}_{\mathrm{sn} \_ \text {inlet }}=10.6^{\circ} \mathrm{C}, \dot{\mathrm{m}}_{\mathrm{mn}}=41.3 \mathrm{~g} \cdot \mathrm{s}^{-1}, \dot{\mathrm{m}}_{\mathrm{sn}}=20.8 \mathrm{~g} \cdot \mathrm{s}^{-1}\right)(\mathrm{Zhu}$ and Elbel, 2020).

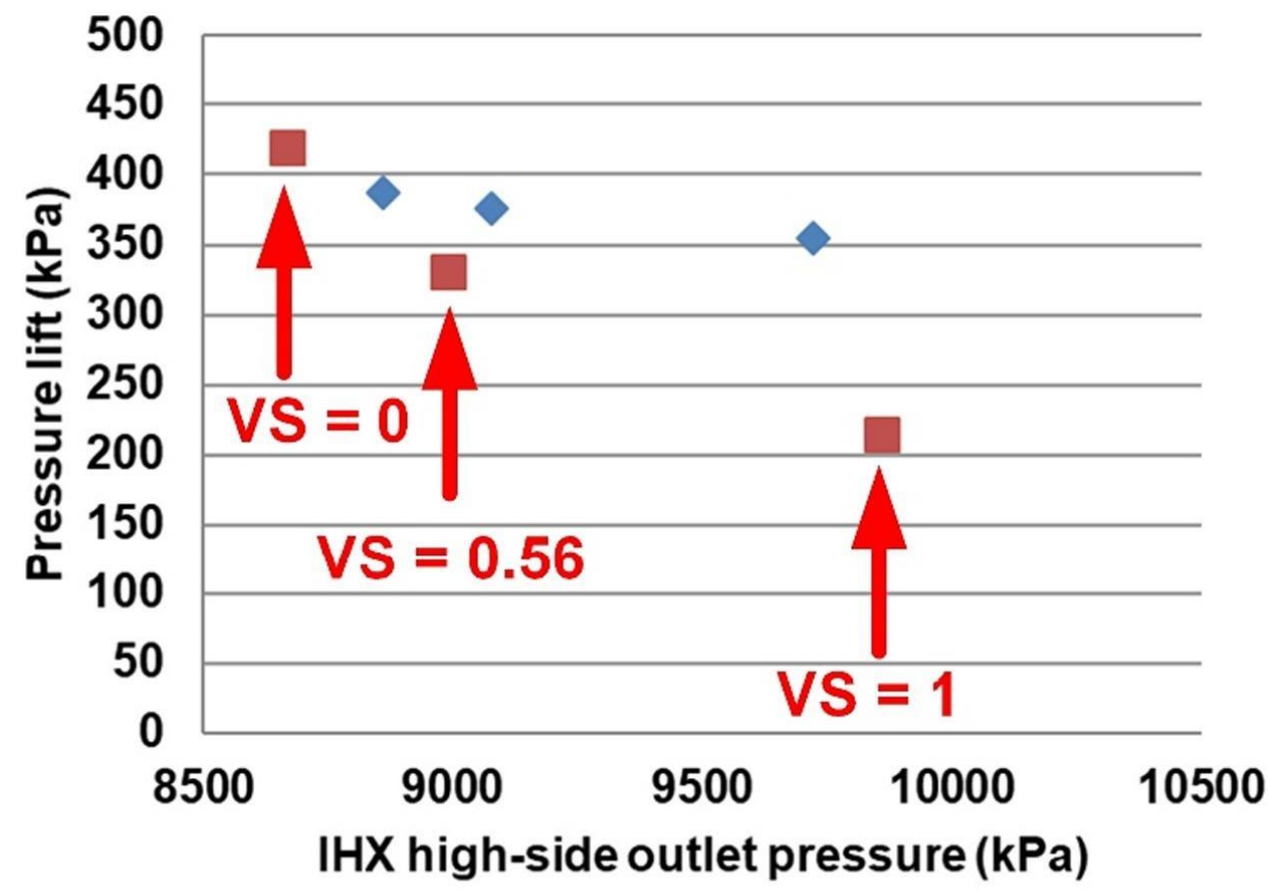

Valve control $\square$ Vortex control

(a)

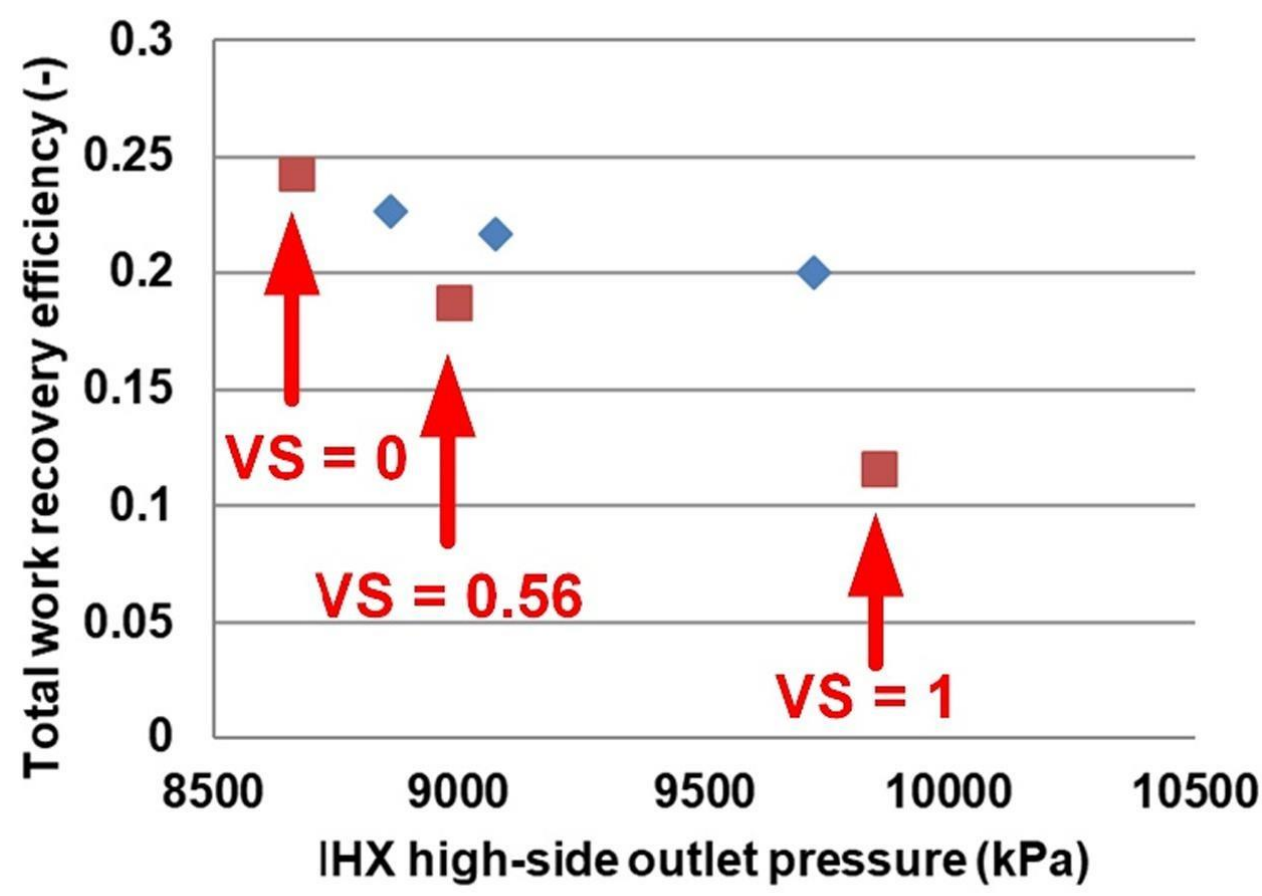

$\bullet$ Valve control

Vortex control

(b) 
Figure 9. Comparison in terms of capacity and COP among series expansion valve control, needle control and vortex control $\left(\mathrm{T}_{\text {air,gc } \_ \text {inlet }}=45^{\circ} \mathrm{C}\right.$, $\left.\mathrm{T}_{\text {air,evap_inlet }}=17.0^{\circ} \mathrm{C}\right)(\mathrm{Zhu}$ and Elbel, 2020).

(a)

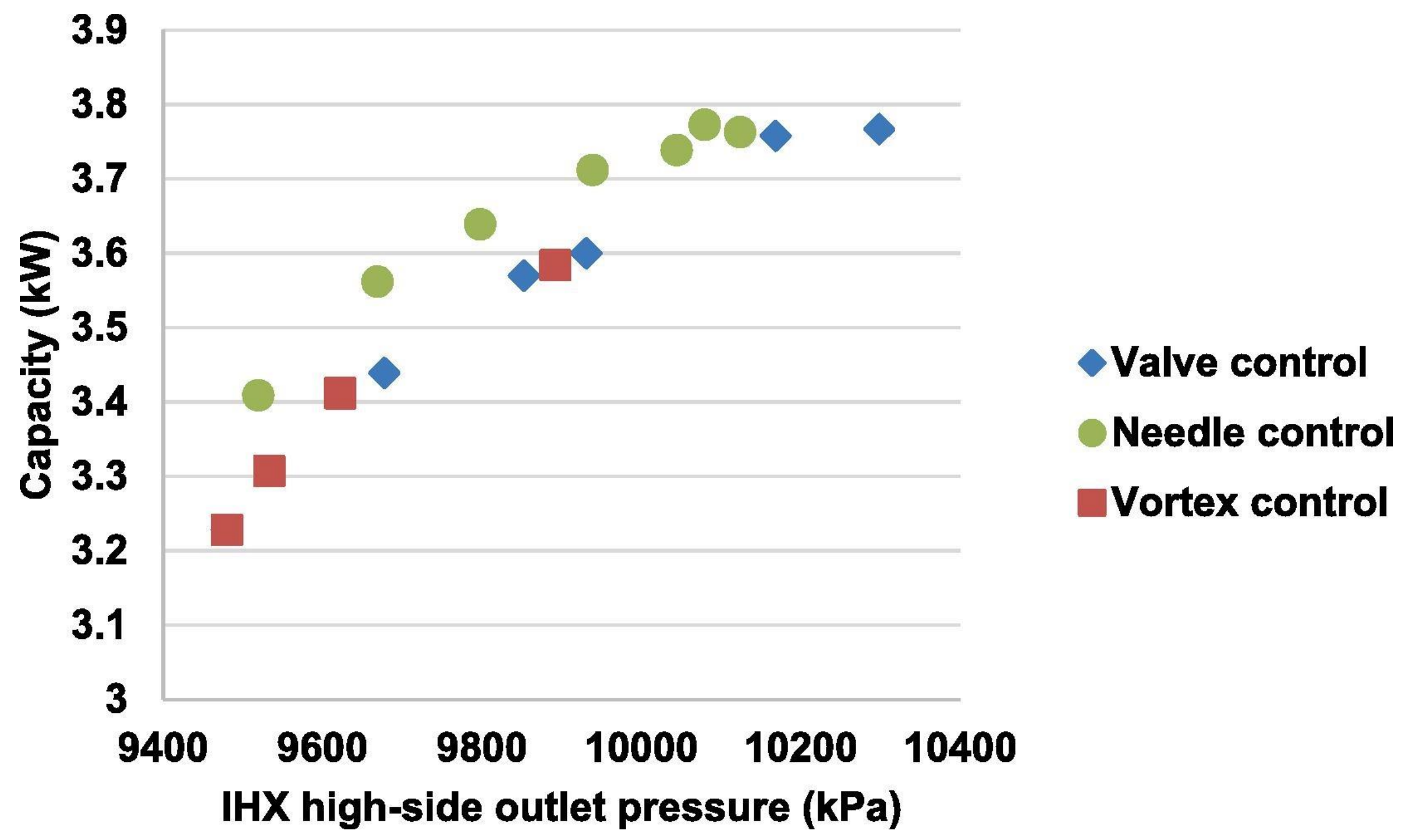


(b)

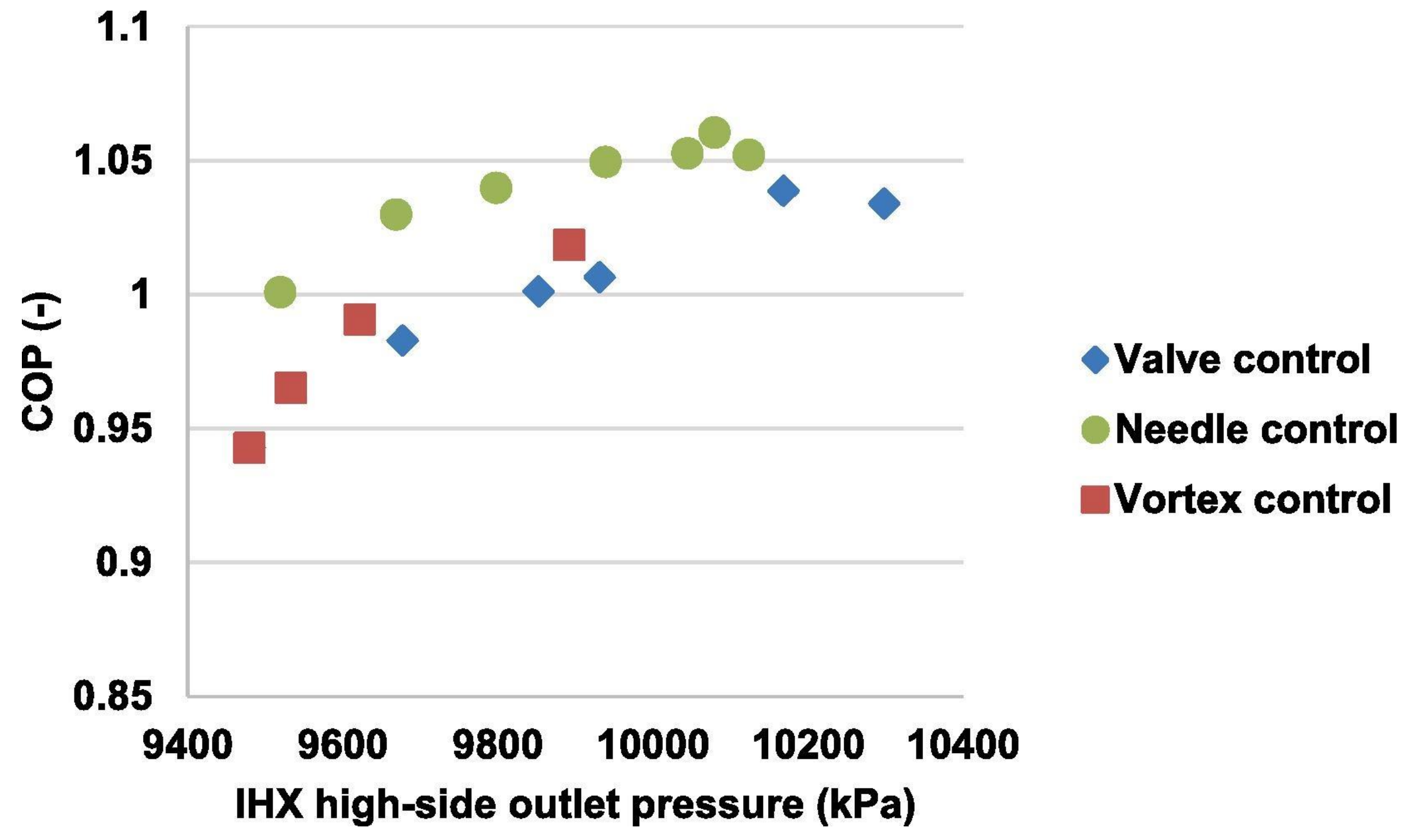


Table 1. Summary of the main findings related to the adjustable needle-based capacity control technique.

\begin{tabular}{|c|c|c|c|}
\hline Reference(s) & $\begin{array}{l}\text { Investigation } \\
\text { typology }\end{array}$ & $\begin{array}{l}\text { Investigated } \\
\text { solution }\end{array}$ & Main findings \\
\hline $\begin{array}{l}\text { Elbel and Hrnjak } \\
\text { (2008) }\end{array}$ & Experimental & $\begin{array}{l}\text { Transcritical R744 air } \\
\text { conditioner }\end{array}$ & $\begin{array}{l}\text { - Ejector efficiencies up to } 0.145 \\
\text { - Potential COP improvements by up to } 18 \% \text { for matched cooling } \\
\text { capacities over the basic solution } \\
\text { - } 2 \% \text { penalization in COP and } 9 \% \text { decrease in capacity as the gas cooler } \\
\text { pressure was } 1.0 \mathrm{MPa} \text { below its optimal value }\end{array}$ \\
\hline Xu et al. (2012) & Experimental & $\begin{array}{l}\text { Transcritical } \mathrm{R} 744 \\
\text { heat pump unit }\end{array}$ & $\begin{array}{l}\text { - Ejector efficiency between } 0.2 \text { and } 0.3 \\
\text { - High pressures optimizing } \mathrm{COP}_{\text {heating }} \text { were lower than those } \\
\text { optimizing heating capacity } \\
\text { - } \mathrm{COP} \text { enhancements up to } 2.1 \% \\
\text { - } 3 \% \text { penalization in COP and } 5 \% \text { decrease in capacity as the gas cooler } \\
\text { pressure was } 0.5 \mathrm{MPa} \text { below its optimal value } \\
\text { - } 4 \% \text { penalization in COP as the gas cooler pressure was } 1.0 \mathrm{MPa} \text { above } \\
\text { its optimal value }\end{array}$ \\
\hline Liu et al. (2012a) & Experimental & $\begin{array}{l}\text { Transcritical R744 air } \\
\text { conditioner }\end{array}$ & $\begin{array}{l}\text { - The higher the outdoor air temperature, the higher the benefits from } \\
\text { the ejector (COP increment by up to } 36 \% \text { and capacity increment by } \\
\text { up to } 40 \% \text { ) } \\
\text { - The higher the outdoor air temperature, the higher the benefits from } \\
\text { the compressor frequency reduction (COP increment by up to } 147 \% \\
\text { and capacity increment by up to } 25 \% \text { ) } \\
\text { - The higher the outdoor air temperature, the higher the benefits from } \\
\text { the reduction of the motive nozzle throat diameter (COP increment } \\
\text { by up to } 60 \% \text { and capacity increment by up to } 46 \% \text { ) }\end{array}$ \\
\hline Liu et al. (2016) & Experimental & $\begin{array}{l}\text { Transcritical R744 } \\
\text { vapour-compression } \\
\text { unit for simultaneous } \\
\text { cooling and heating }\end{array}$ & $\begin{array}{l}\text { - COP increment by up to } 71.4 \% \text {, whereas system capacity decrement } \\
\text { by } 21.3 \%\end{array}$ \\
\hline
\end{tabular}




\begin{tabular}{|c|c|c|c|}
\hline Liu et al. (2012c) & \begin{tabular}{|l|} 
Simulation \\
model \\
validated \\
against \\
experiments \\
\end{tabular} & $\begin{array}{lr}\text { Transcritical } & \mathrm{R} 744 \\
\text { (air-to-air) } & \text { air } \\
\text { conditioner } & \end{array}$ & $\begin{array}{l}\text { - COP improvements by about } 30.7 \% \text { at the outdoor air temperature of } \\
37.8^{\circ} \mathrm{C} \\
\text { - Capacity improvements by about } 32.1 \% \text { at the outdoor air } \\
\text { temperature of } 37.8^{\circ} \mathrm{C}\end{array}$ \\
\hline Hu et al. (2014) & Experimental & $\begin{array}{lr}\text { R410A } & \text { vapour- } \\
\text { compression } & \text { air- } \\
\text { conditioner } & \end{array}$ & $\begin{array}{l}\text { - Slightly different geometries cause considerably different EERs at the } \\
\text { same boundary conditions } \\
\text { - Limited increment in EER compared to the unit using an electronic } \\
\text { expansion valve }\end{array}$ \\
\hline $\begin{array}{lll}\begin{array}{l}\text { Zheng } \\
(2016)\end{array} & \text { et al. }\end{array}$ & $\begin{array}{l}\text { Simulation } \\
\text { model } \\
\text { validated } \\
\text { against } \\
\text { experiments }\end{array}$ & $\begin{array}{l}\text { Transcritical } \mathrm{R} 744 \\
\text { vapour-compression } \\
\text { units }\end{array}$ & $\begin{array}{l}\text { - COP between } 2.10 \text { and } 2.50 \text { for the conventional ejector-equipped } \\
\text { transcritical R744 vapour-compression unit } \\
\text { - COP between } 2.40 \text { and } 3.58 \text { for the ejector-equipped transcritical } \\
\text { R744 vapour-compression unit using two-stage evaporation }\end{array}$ \\
\hline $\begin{array}{l}\text { Lawrence and } \\
\text { Elbel (2016a, } \\
2016 c, 2019)\end{array}$ & Experimental & $\begin{array}{l}\text { Transcritical R744 air } \\
\text { conditioner }\end{array}$ & $\begin{array}{l}\text { - Improvements in COP between } 2 \% \text { and } 4 \% \text { in comparison with } \\
\text { conventional passive ejector system }\end{array}$ \\
\hline He et al. (2019) & Experimental & $\begin{array}{l}\text { Transcritical } \mathrm{R} 744 \\
\text { vapour-compression } \\
\text { unit }\end{array}$ & $\begin{array}{l}\text { - } 5 \% \div 11 \% \text { lower entrainment ratio than for a passive ejector due to the } \\
\text { significant exergy destruction occurring in suction chamber }\end{array}$ \\
\hline $\begin{array}{l}\text { Jeon et al. } \\
(2017 b)\end{array}$ & Experimental & $\begin{array}{l}\text { R600a domestic } \\
\text { refrigerator-freezer } \\
\text { with condenser outlet } \\
\text { split }\end{array}$ & $\begin{array}{l}\text { - Maximum COP enhancement of } 6.8 \% \text { in comparison with a } \\
\text { conventional vapour-compression unit }\end{array}$ \\
\hline Jeon et al. (2018) & Experimental & $\begin{array}{l}\text { R600a domestic } \\
\text { refrigerator-freezer } \\
\text { with condenser outlet } \\
\text { split }\end{array}$ & $\begin{array}{l}\text { - Energy savings of } 10.9 \% \text { in comparison with a conventional vapour- } \\
\text { compression unit at the similar cooling duty and compressor speed of } \\
1450 \mathrm{rpm}\end{array}$ \\
\hline
\end{tabular}


Table 2. Summary of the main findings related to the multi-ejector based capacity control technique.

\begin{tabular}{|c|c|c|c|}
\hline Reference(s) & $\begin{array}{l}\text { Investigation } \\
\text { typology }\end{array}$ & $\begin{array}{l}\text { Investigated } \\
\text { solution }\end{array}$ & Main findings \\
\hline $\begin{array}{l}\text { Banasiak et al. } \\
(2015)\end{array}$ & Experimental & $\begin{array}{l}\text { Transcritical } \mathrm{R} 744 \\
\text { supermarket } \\
\text { refrigeration system }\end{array}$ & $\begin{array}{l}\text { - Multi-ejector block could appropriately control the capacity } \\
\text { - Ejector efficiencies above } 0.3 \text { and a maximum COP improvement by } \\
9.8 \%\end{array}$ \\
\hline $\begin{array}{l}\text { Haida et al. } \\
(2016)\end{array}$ & Experimental & $\begin{array}{l}\text { Transcritical } \mathrm{R} 744 \\
\text { refrigeration system }\end{array}$ & $\begin{array}{l}\text { - COP and exergy efficiency improvement by up to } 7 \% \text { and } 13.7 \% \\
\text { - Ejector efficiencies up to } 0.33\end{array}$ \\
\hline $\begin{array}{l}\text { Fredslund et al. } \\
\text { (2016) }\end{array}$ & $\begin{array}{l}\text { Field } \\
\text { measurements }\end{array}$ & $\begin{array}{l}\text { Transcritical } \mathrm{R} 744 \\
\text { supermarket } \\
\text { refrigeration system }\end{array}$ & $\begin{array}{l}\text { - Ejector efficiencies derived from field measurements were found to } \\
\text { be similar (and above } 0.25 \text { ) to those assessed in the laboratory }\end{array}$ \\
\hline $\begin{array}{l}\text { Bodys et al. } \\
(2017)\end{array}$ & Experimental & $\begin{array}{l}\text { Transcritical } \mathrm{R} 744 \\
\text { refrigeration system }\end{array}$ & $\begin{array}{l}\text { - Adoption of multi-ejector module leads supermarket refrigeration } \\
\text { systems to high and stable performance }\end{array}$ \\
\hline $\begin{array}{l}\text { Schönenberger et } \\
\text { al. (2014) and } \\
\text { Hafner et al. } \\
(2014 \mathrm{~b})\end{array}$ & $\begin{array}{l}\text { Field } \\
\text { measurements }\end{array}$ & $\begin{array}{l}\text { Transcritical } \mathrm{R} 744 \\
\text { supermarket } \\
\text { refrigeration system }\end{array}$ & $\begin{array}{l}\text { - Energy savings between } 10 \% \text { and } 14 \% \text { in comparison with the } \\
\text { solution equipped with parallel compression in cold climates }\end{array}$ \\
\hline $\begin{array}{l}\text { Hafner et al. } \\
(2016)\end{array}$ & $\begin{array}{l}\text { Field } \\
\text { measurements }\end{array}$ & $\begin{array}{l}\text { Transcritical } \mathrm{R} 744 \\
\text { supermarket } \\
\text { refrigeration system }\end{array}$ & $\begin{array}{l}\text { - At external ambient temperatures between } 22{ }^{\circ} \mathrm{C} \text { and } 35^{\circ} \mathrm{C} \text {, energy } \\
\text { savings between } 15 \% \text { and } 30 \% \text { (depending on the AC demand and } \\
\text { outdoor temperature) in comparison with parallel compression }\end{array}$ \\
\hline $\begin{array}{l}\text { Boccardi et al. } \\
(2016,2017)\end{array}$ & Experimental & $\begin{array}{l}\text { Transcritical } \mathrm{R} 744 \\
\text { heat pump unit }\end{array}$ & $\begin{array}{l}\text { - Lack of investigations on multi-ejector based transcritical R744 heat } \\
\text { pump systems }\end{array}$ \\
\hline
\end{tabular}


Table 3. Summary of the main findings related to the adjustable vortex-based capacity control technique.

\begin{tabular}{|l|l|l|l|}
\hline Reference & $\begin{array}{l}\text { Investigation } \\
\text { typology }\end{array}$ & $\begin{array}{l}\text { Investigated } \\
\text { solution }\end{array}$ & Main findings \\
\hline $\begin{array}{l}\text { Zhu and Elbel } \\
(2016 \mathrm{~b})\end{array}$ & Experimental & $\begin{array}{l}\text { R134a vapour- } \\
\text { compression system }\end{array}$ & $\begin{array}{l}\text { At the inlet and outlet conditions, mass flow rate can be decreased by } \\
36 \%\end{array}$ \\
\hline $\begin{array}{l}\text { Zhu and Elbel } \\
(2018 \mathrm{~d})\end{array}$ & Experimental & $\begin{array}{l}\text { R134a vapour- } \\
\text { compression system }\end{array}$ & $\bullet$ A maximum vortex control range of 42\% was observed \\
\hline $\begin{array}{l}\text { Zhu and Elbel } \\
(2018 \mathrm{a})\end{array}$ & Experimental & $\begin{array}{l}\text { Transcritical R744 } \\
\text { vapour-compression } \\
\text { system for MAC } \\
\text { applications }\end{array}$ & $\begin{array}{l}\text { Motive inlet pressure could be varied between } 86.09 \text { bar and } 96.37 \\
\text { bar for constant total motive mass flow rate and motive inlet } \\
\text { temperature } \\
\text { Decrements in vortex ejector efficiency by about } 47 \% \text { from } 0.187 \text { to } \\
0.099 \text { with rise in vortex strength }\end{array}$ \\
\hline $\begin{array}{l}\text { Zhu and Elbel } \\
(2020)\end{array}$ & Experimental & $\begin{array}{l}\text { Transcritical R744 } \\
\text { vapour-compression } \\
\text { system }\end{array}$ & $\begin{array}{l}\text { System capacity and COP improvements by } 11 \% \text { and } 8.1 \% \text { under off- } \\
\text { design running modes, respectively. }\end{array}$ \\
\hline
\end{tabular}

The accepted manuscript can be freely downloaded at: https://paridegullo.academia.edu/research 
Table 4. Pros and cons comparison of the available capacity control techniques for two-phase ejectors.

\begin{tabular}{|c|c|c|c|}
\hline $\begin{array}{l}\text { Evaluated capacity } \\
\text { control techniques }\end{array}$ & Compared to & Pros & Cons \\
\hline Needle-based ejector & - & $\begin{array}{l}\text { - Ejector capacity modulation can be } \\
\text { implemented }\end{array}$ & $\begin{array}{l}\text { - Close attention needs to be paid } \\
\text { to the problems related to a } \\
\text { complicated and difficult system } \\
\text { control to meet the various } \\
\text { cooling needs (Lin et al., 2012) } \\
\text { - Trustworthiness of the ejector } \\
\text { could be threatened by the } \\
\text { presence of moving parts } \\
\text { (Boccardi et al., 2017) } \\
\text { - Need for optimization of mixer } \\
\text { and diffuser geometry as well as } \\
\text { a function of the operation } \\
\text { conditions (Boccardi et al., 2017) } \\
\text { - Needle position was difficult to } \\
\text { be unequivocally assessed } \\
\text { (Smolka et al., 2016) } \\
\text { - Lack of field measurements and } \\
\text { evidence of reliability from rea } \\
\text { applications (Girotto, 2017) }\end{array}$ \\
\hline & Multi-ejector & - No constraints in terms application size & $\begin{array}{l}\text { - Only the throat is adapted to the } \\
\text { operating conditions, whereas in } \\
\text { multi-ejector all characteristic } \\
\text { sizes (mixing section, etc.) get } \\
\text { varied at the same time }\end{array}$ \\
\hline
\end{tabular}




\begin{tabular}{|c|c|c|c|}
\hline Vortex-based ejector & Needle-based ejector & $\begin{array}{l}\text { - Simpler, (potentially) less costly, less } \\
\text { vulnerable to clogging and subject to } \\
\text { lower frictional losses (Zhu and Elbel, } \\
\text { 2016a, 2016b) }\end{array}$ & $\begin{array}{l}\text { - Still under investigation on } \\
\text { laboratory scale }\end{array}$ \\
\hline Multi-ejector & $\begin{array}{l}\text { Needle-based ejector } \\
\text { and vortex-based ejector }\end{array}$ & $\begin{array}{l}\text { - Considerably used in medium- and } \\
\text { large-applications }\end{array}$ & $\begin{array}{l}\text { - Too complicated (Elbel and } \\
\text { Lawrence, 2016), expensive } \\
\text { (Madsen and Kriezi, 2018; Zhu } \\
\text { and Elbel, 2020) and limited by } \\
\text { manufacturing sizes for small- } \\
\text { capacity applications }\end{array}$ \\
\hline
\end{tabular}

The accepted manuscript can be freely downloaded at: https://paridegullo.academia.edu/research 
Table 5. Performance comparison of the available capacity control techniques for two-phase ejectors.

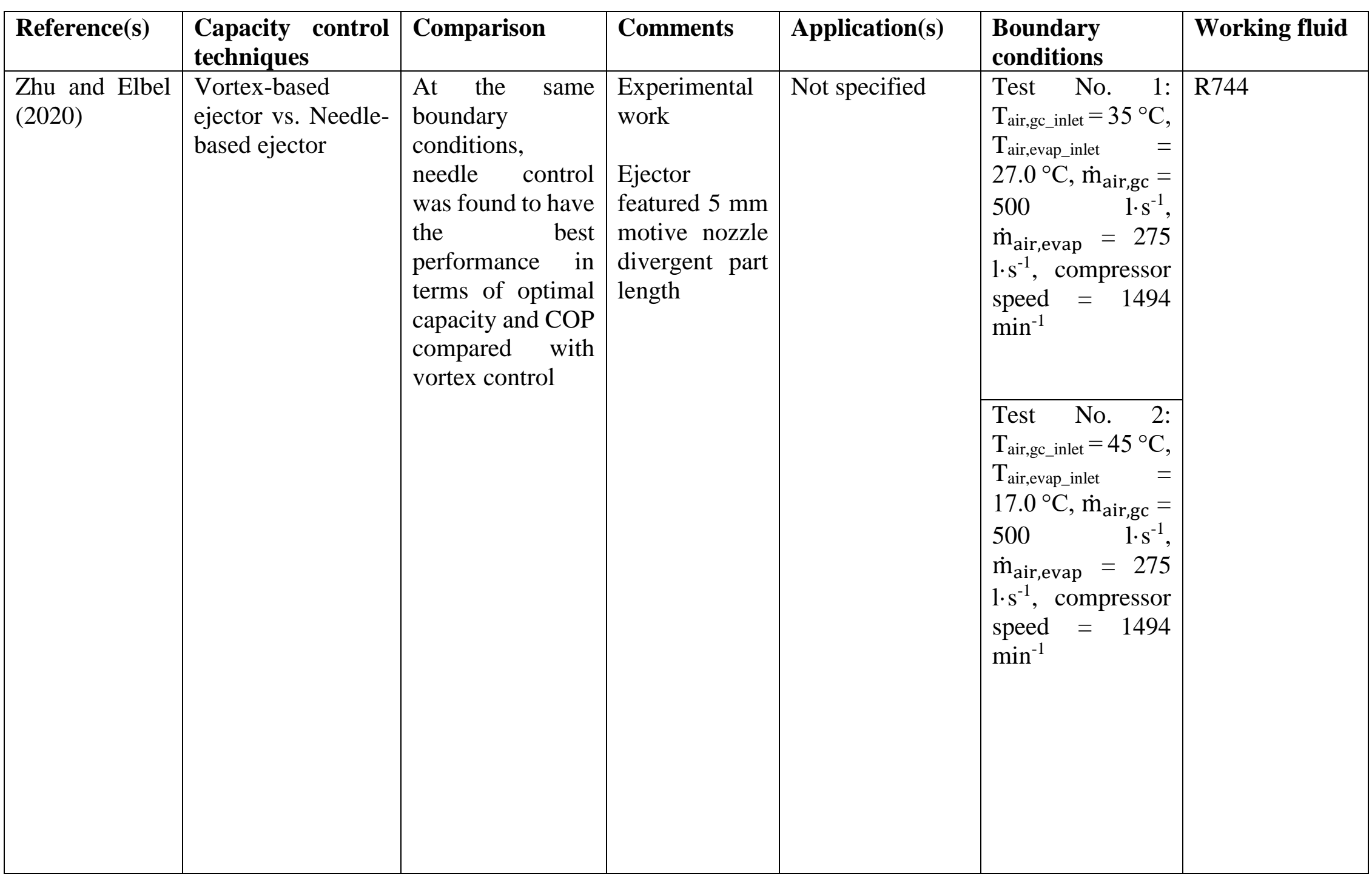


The accepted manuscript can be freely downloaded at: https://paridegullo.academia.edu/research

\begin{tabular}{|c|c|c|c|c|c|c|}
\hline $\begin{array}{l}\text { Zhu and Elbel } \\
(2018 \mathrm{a}, 2018 \mathrm{~b}, \\
2018 \mathrm{c}) \text { and } \\
\text { (Lawrence, } \\
2016)\end{array}$ & $\begin{array}{l}\text { Vortex-based } \\
\text { ejector vs. Needle- } \\
\text { based ejector }\end{array}$ & $\begin{array}{l}\text { At similar } \\
\text { boundary } \\
\text { conditions, vortex } \\
\text { ejector efficiency } \\
\text { reduced by about } \\
47 \% \text { from } 0.187 \\
\text { to } 0.099 \text { with } \\
\text { increase in vortex } \\
\text { strength (Zhu and } \\
\text { Elbel, 2018a, } \\
2018 b, 2018 \mathrm{c} \text { ), } \\
\text { whereas needle- } \\
\text { based ejector } \\
\text { efficiency } \\
\text { decreased by 35\% } \\
\text { from } 0.23 \text { to } 0.15 \\
\text { with increase in } \\
\text { high pressure } \\
\text { (Lawrence, 2016) }\end{array}$ & $\begin{array}{l}\text { Experimental } \\
\text { results } \\
\text { The geometric } \\
\text { parameters } \\
\text { were the same } \\
\text { for both } \\
\text { ejectors, i.e. } \\
\text { vortex ejector } \\
\text { was not } \\
\text { designed to } \\
\text { cope with the } \\
\text { vortex control }\end{array}$ & $\begin{array}{l}\text { MAC and air } \\
\text { conditioning }\end{array}$ & $\begin{array}{l}\mathrm{T}_{\mathrm{mn} \text { inlet }}=31.50 \\
{ }^{\circ} \mathrm{C}, \quad \mathrm{P}_{\mathrm{gc}}= \\
86.09 \div 96.37 \text { bar, } \\
\mathrm{P}_{\text {sn_inlet }}=33.00 \\
\text { bar, } \dot{\mathrm{Q}}_{\text {cooling }}= \\
5.00 \div 7.00 \mathrm{~kW}\end{array}$ & R744 \\
\hline
\end{tabular}

The accepted manuscript can be freely downloaded at: https://paridegullo.academia.edu/research 


\section{${ }^{*}$ Declaration of Interest Statement}

The accepted manuscript can be freely downloaded at: https://paridegullo.academia.edu/research

\section{Declaration of interests}

$\bigotimes$ The authors declare that they have no known competing financial interests or personal relationships that could have appeared to influence the work reported in this paper.

$\square$ The authors declare the following financial interests/personal relationships which may be considered as potential competing interests:

The accepted manuscript can be freely downloaded at: https://paridegullo.academia.edu/research 